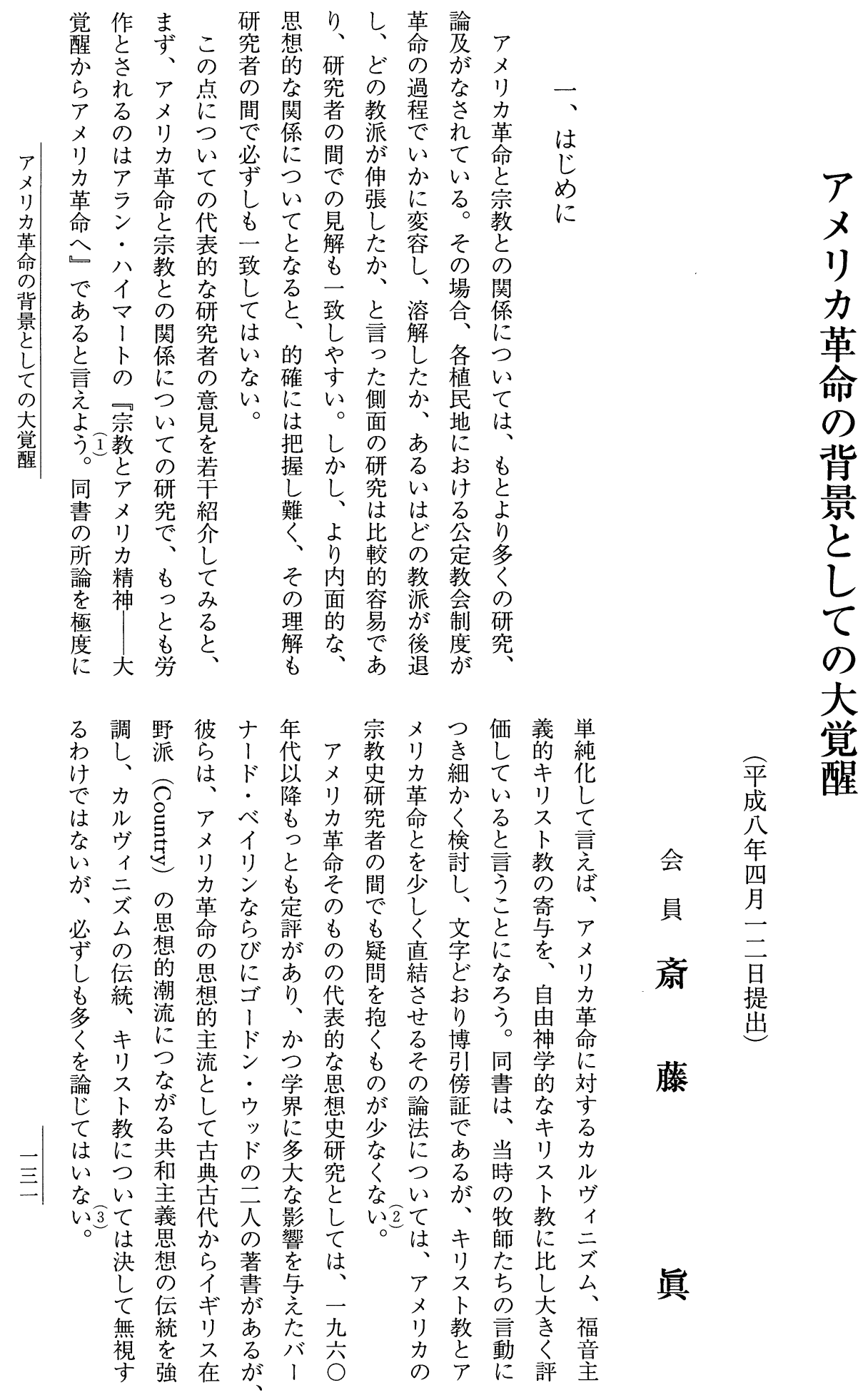




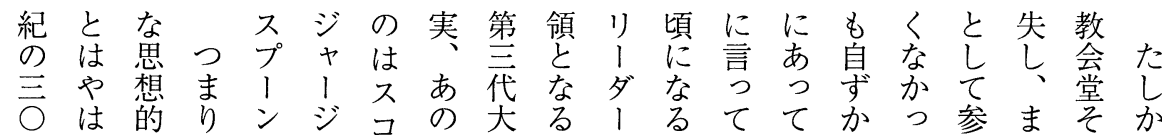

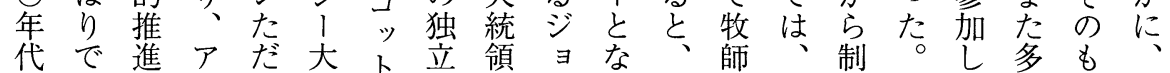

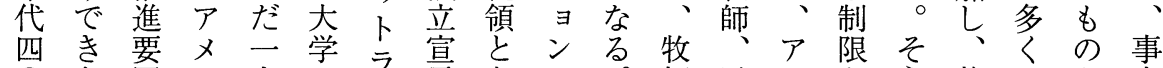

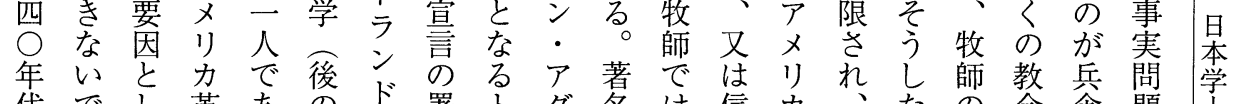
代でし 革あ の

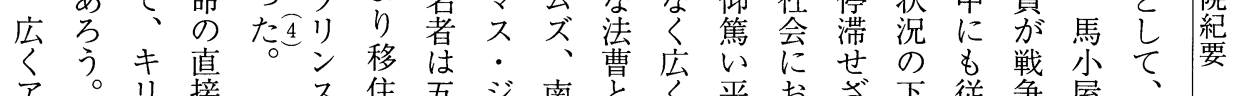
ア。门接不住五ジ南是平市ざ下従争屋、、

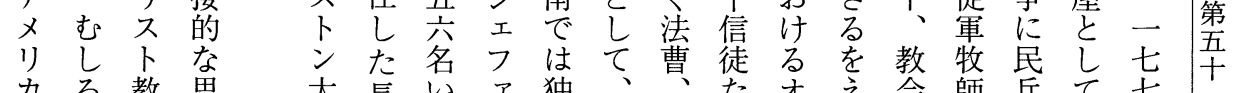

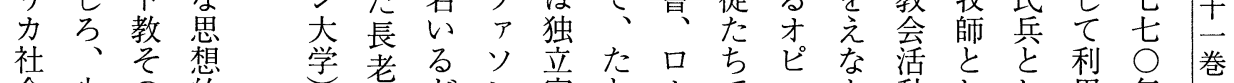

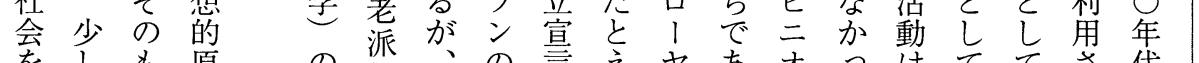

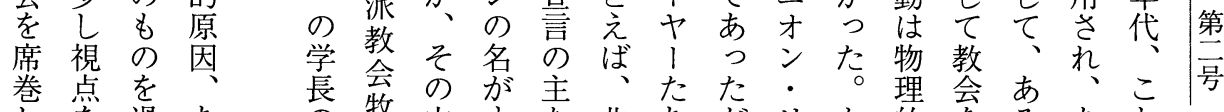

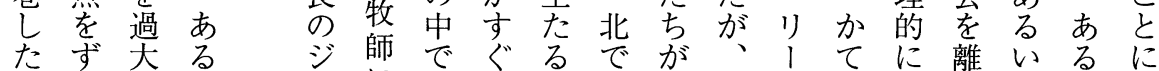
信らにいに牧思起は牙名てもも执はい独

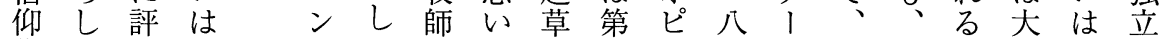

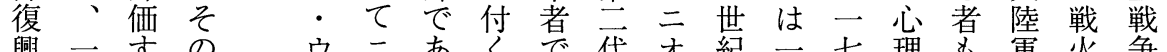

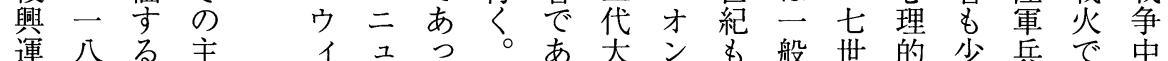

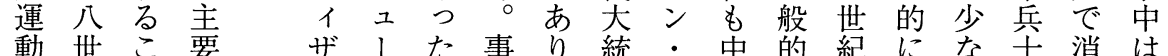
動世こ要ザリた事り、統・中的紀にな士消は

教 求自ちつ教てすキ

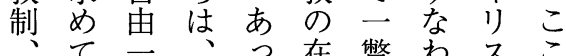
礼移般ごたりし帒占で 捂 住をく方方て 公 教 様し求二ら㤎扮費会大 式ため部で、きに学 信で移分るでいう況に 条あ住離。に。てをつ社 内可し 派ま植と特会

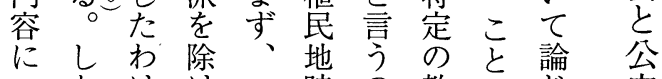
つたけけ二時の教にじ定 いがでばュ代も派公音教 て批てな時イ年ア教教提会 判々に主 た彼彼誤グ解ラロ少牧制 て には方さシッ社師君 せ全自尔パ会を索植 よ゙ギ身で の の に 教 ス 信るさュれけるる。社 会国仰が、と交制会 を教の、リ異キ度忌に 公会自信夕なりに落お

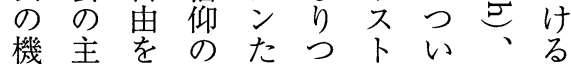

とは係すが下社で 理 個にべ起地会 あ 解人つきこににる しのいでりな も 大 た救ては、るた覚 植 い兵済はなア状ら醒 民民に か $\mathrm{W}$ 少少敢社常 わ $\mathrm{G}$ 加革 え 会 り、穴な

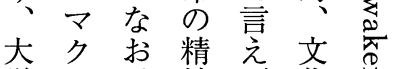
覚亏神芯花导。 醒 ᄀ信的植的 はリ仰背民な 社ン復景地恋に 解造一に六 文瀵君占般注 花に连れ会ほ 全従导つ間しり

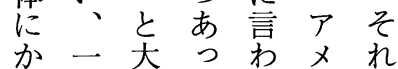
か応覚たばリが わ 信 醒 事 意 カ る仰とに識鞀

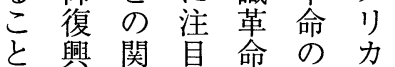




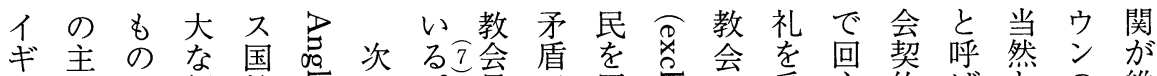

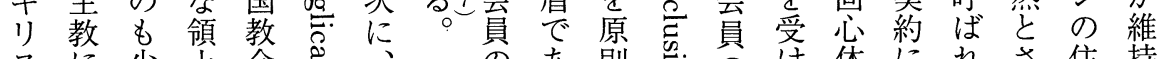
スに少土会寻少則㐫の体にれさ住持

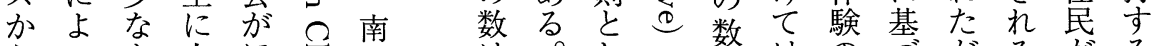

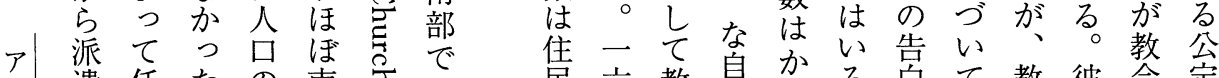

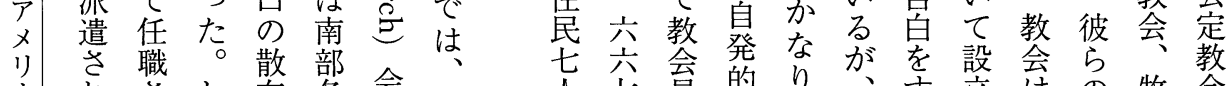

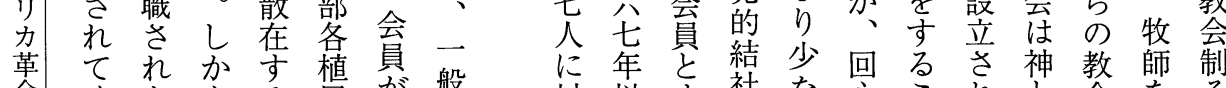
满て れ のるけ背る、植地移に降るとく告と接教財の

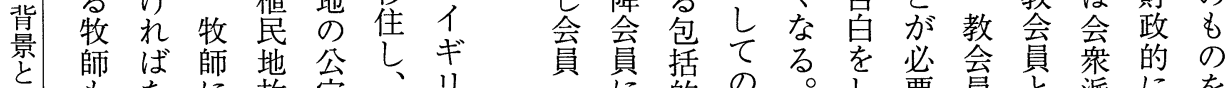

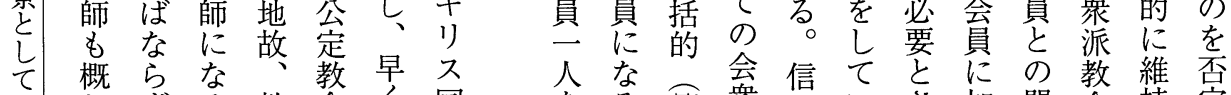

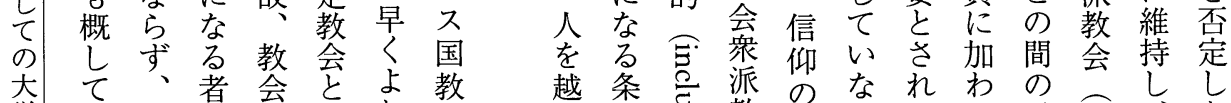

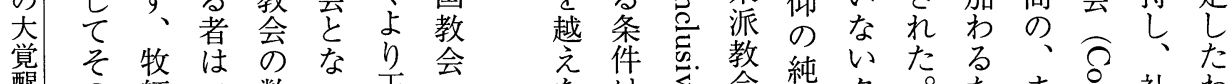

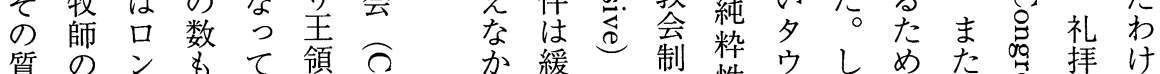

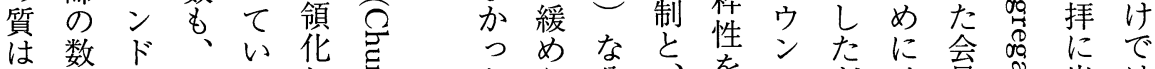

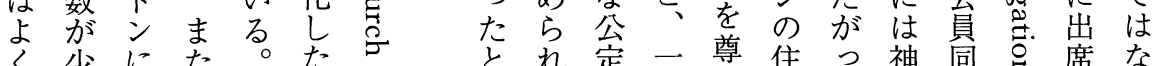
く少にた。た故虽定定尊售つ神同导席な

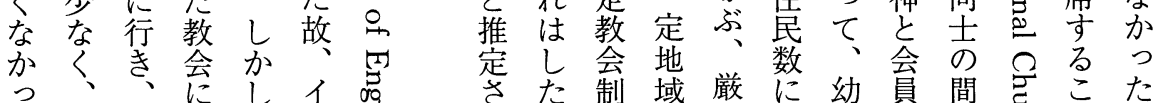

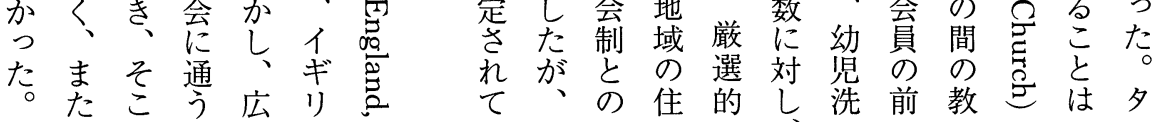

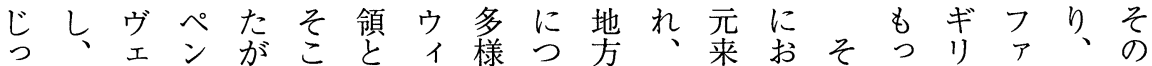
て長三シつにしリ华れ究後才けしてスソ多結

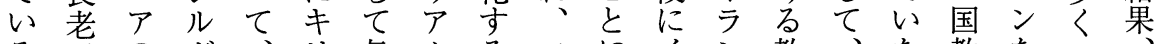
る派のヴ、リ当ムるフににイン教、な教なの

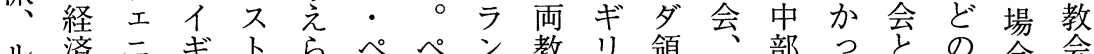
多的矛教れンンス派ス頑教のたはよ弇会 1発地スのたがシの方領あ派二の言う方寒 派展方の枠も国儿新公とつの土でうな名権

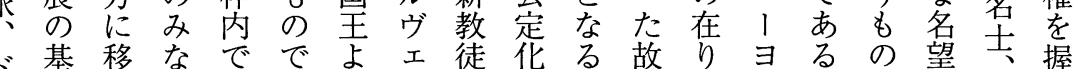

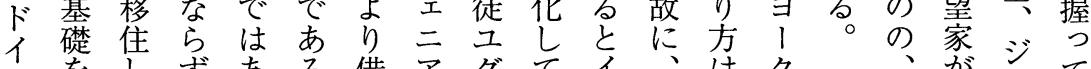

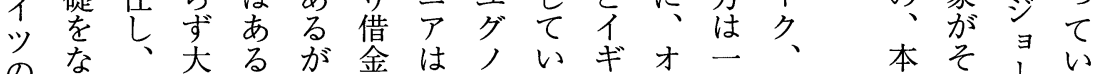

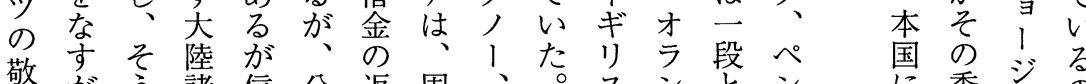

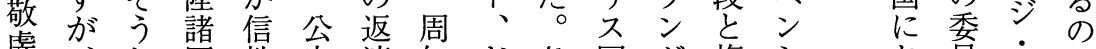

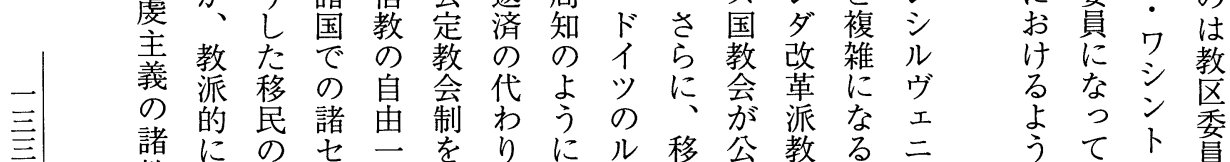

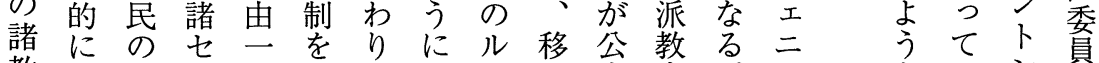

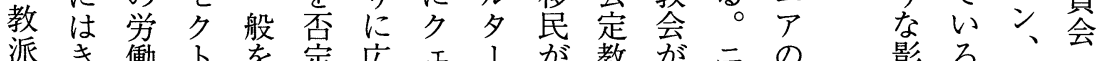

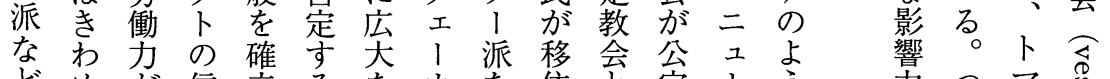

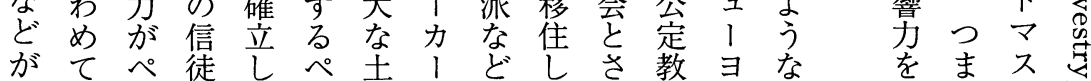

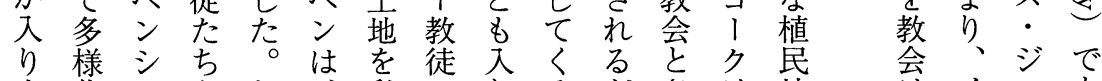

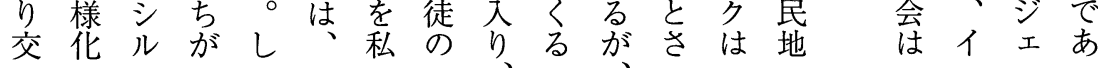


た者空帯

こは間㤂こ

を孛て 拡 西 ご 三

意も大部 、

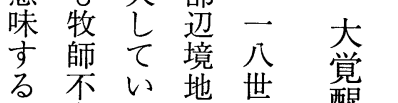

る 不い地 世罢

さの。へ 初

ら空そ人葉

に間の口の

がこがア

亿多と移 メ

ギくは動り

リ存鄙力

在 教、社

中紊そ会

心、未 開 顧

と存接拓 み

こ 在 存が 進と、

ヨざしみみ、

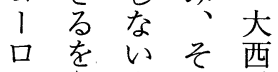

๗ 空の洋

パな 間 意沿

よかか 味 岸
その植教 教 あ 空がロ ジて ニ

もセ民会会る間取 lいヤ的

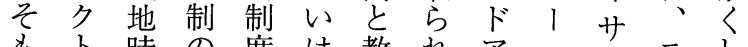

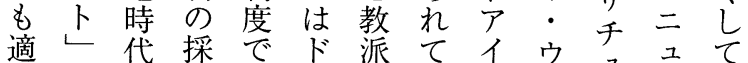

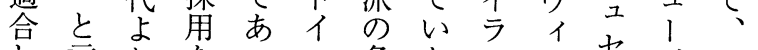

し 言りなつツ多た た リ セ

えう存どた諸様わ施ア高公本

い!現言のにで除台湾涪紀

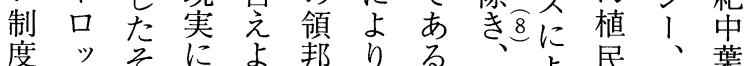

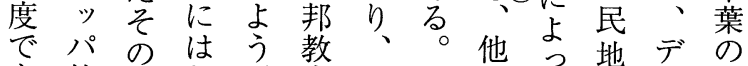
あ的多お。会イしのうてを劣 つな文よま制ンが九建追ウメ

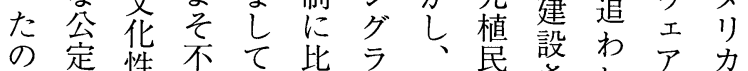

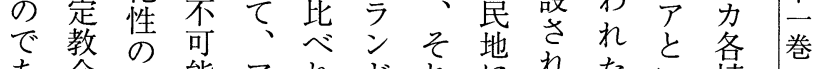
あ会故能アれドれにれたい植 る帛制になメばにらおた元っ民

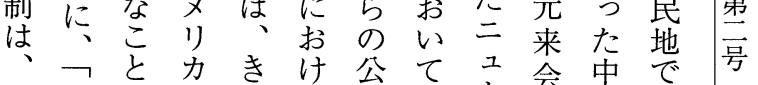
ア 二 で全わ方定は リのうにで会応ン派植ぺ 力教た扮脆り制公グ系想ン 社 会。よ弱 不定 ラ の 地 シ に複ま 公公教㚐会 ド教そ省 は数り、定定会な制のロししエ

圏かて に

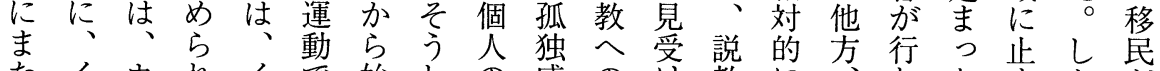
たイウれイ華始しの感のけ教にに方行た业が

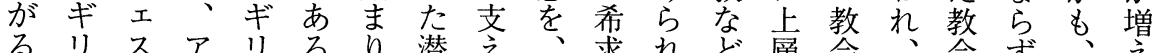
る運ス

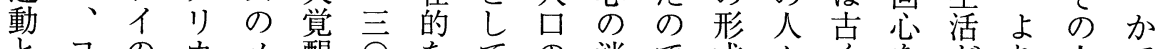
とヨのカメ醒 い! 前にツに年宗の増失あ化をよ体困よ々て

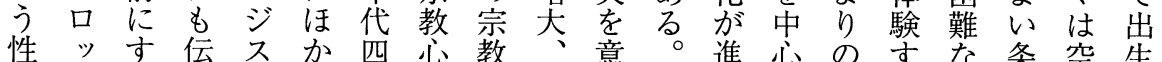
性パす伝 ス か 四心教、意。進心 の名な条空生 も大につ派ら年二求様市加しし頜者と件間率 あ陸アたのな代挙め化るして、求に高

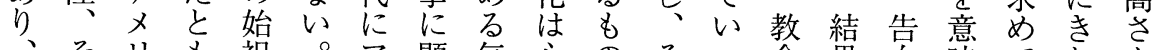
ましりカ考祖な

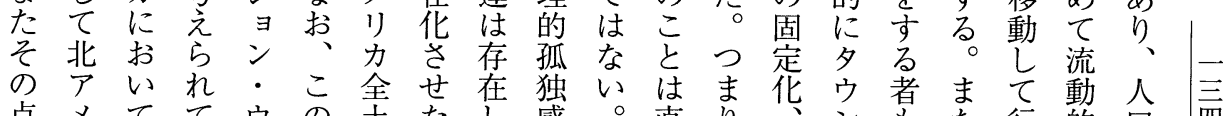

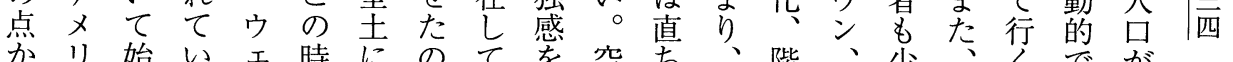
かリ始いエ時にのて空ち充、階、少、くでが

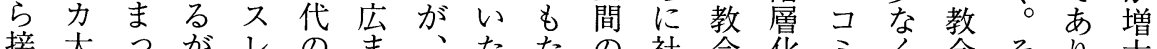

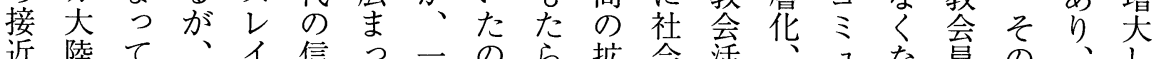

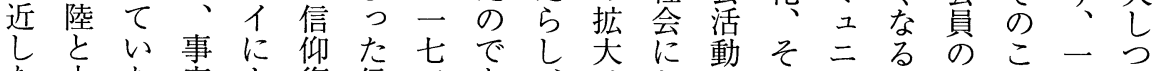

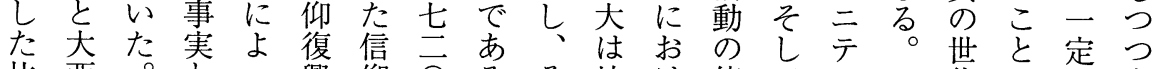
此西洋 確して 運復年。们こ地 け停て 


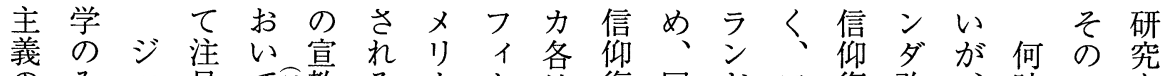
のみヨ自て不教る力、地復回ドア復改、時アを 文なナさ、姿 ゙社ルを興心西メ興革事かメ最 献らサ机勎き会ド説運の部り分派実らり近 ア| も

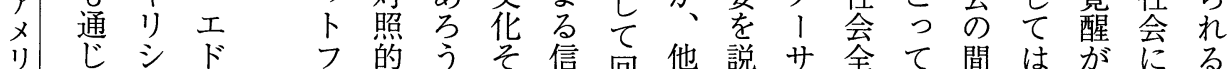
リじジ゙ フ的う泉信回他説サ全て間はがにる

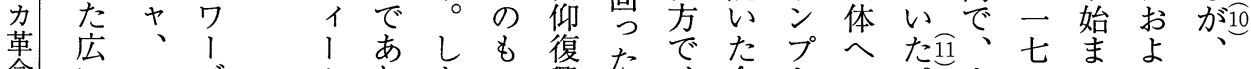

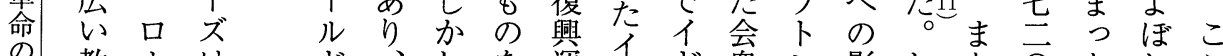

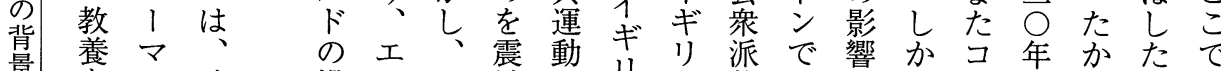

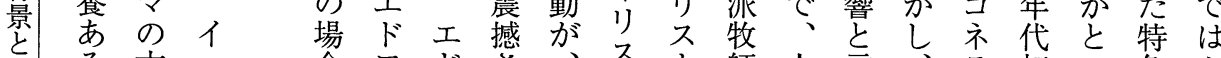

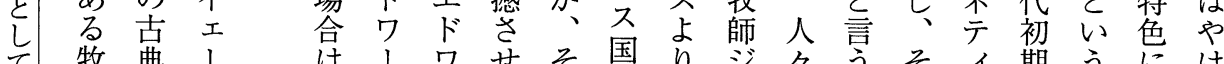

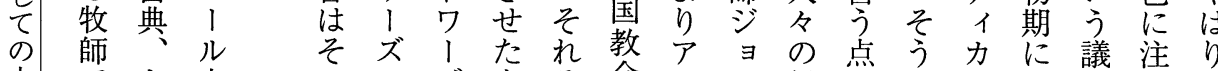

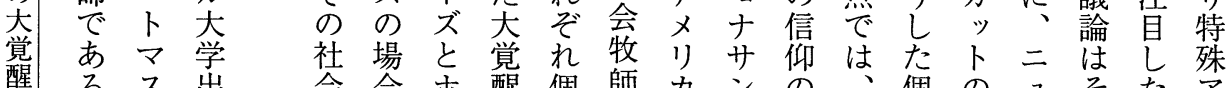
が、出会合木醒個師ガンのの、個のュそたア 、アで影々ッ始、訪エ退方の衆ジほ。リ

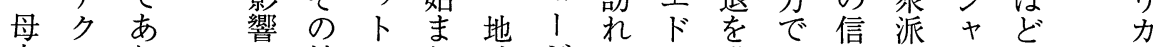

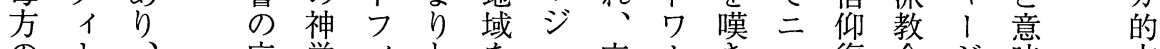

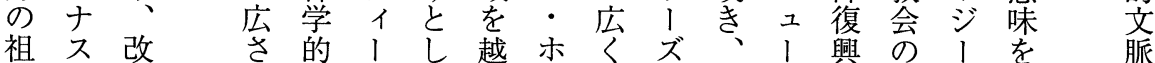

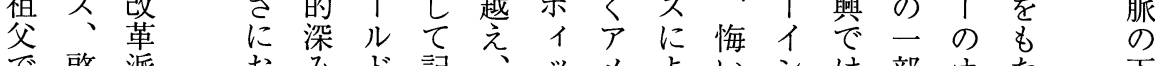

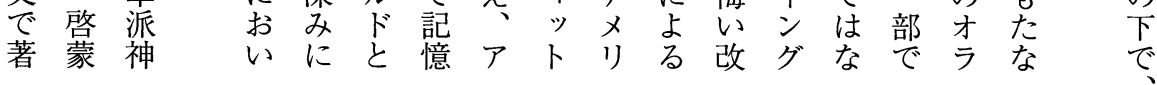
他蓪師 ○神自ワつ罪彼息て語推ワ読でサ名

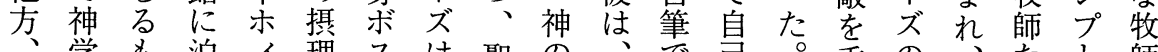

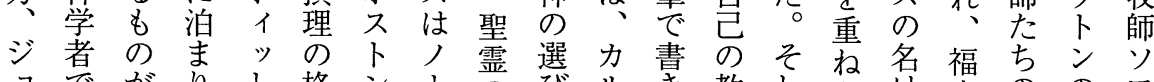

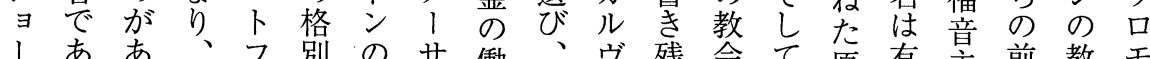

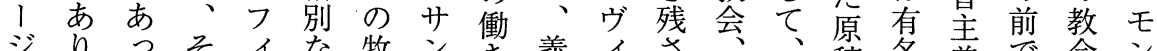

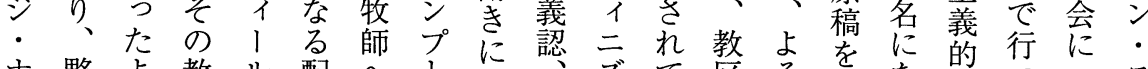

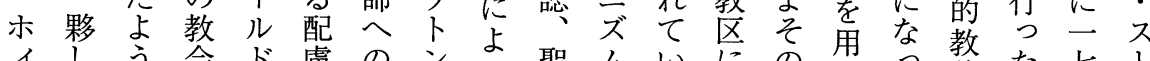
$1 し$ う会ド慮のジる聖㕕いに意な孝た義た七ト

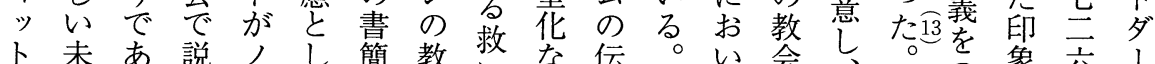

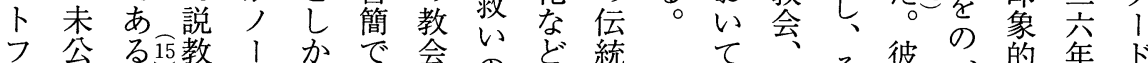

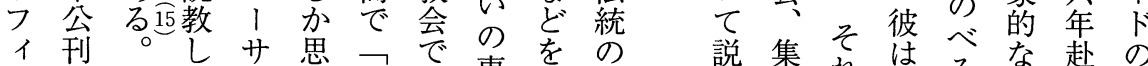
リのしたン岂こ会恵基下説集れ訟る講任牧

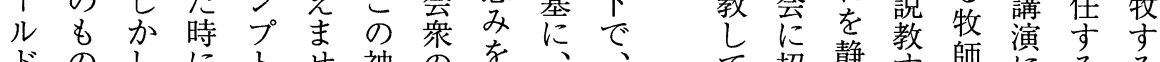
ドのしにトせ神の䛠会神衸照静势師ににるる

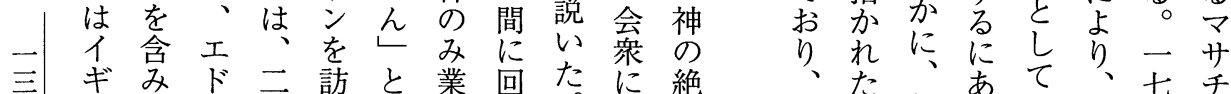

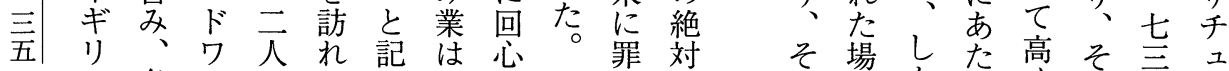

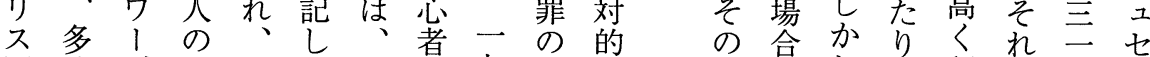
国くズ間エてあ老七悔主説拿し、評が年ッ 教ののにドいら輩言い権教除訴十価印七ツ 会著本はワる苂ゆ出四改、の学分さ刷月の

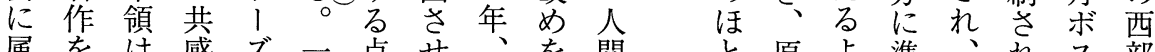

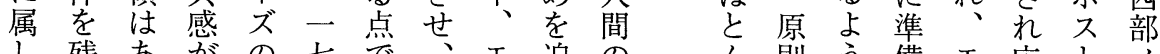

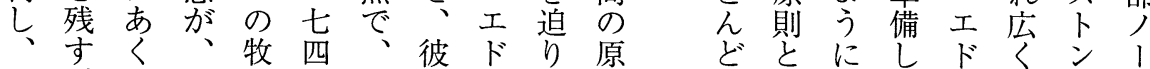




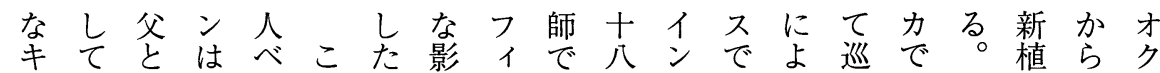

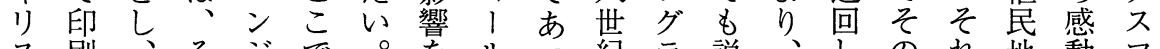
ス刷、そジで。妾ルう紀ラ説、しのれ地動フ 卜所教のさ、与ドた大夺教き、生以棌的才

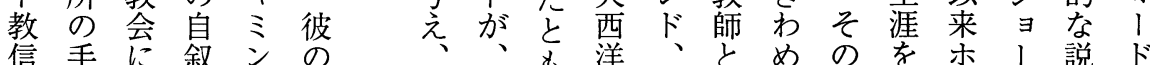

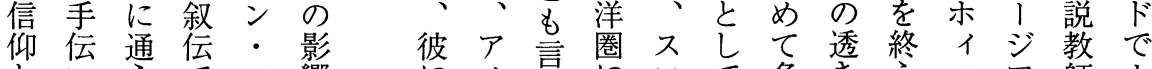
というでフ響にメ言にコて多き等ッア師ウ

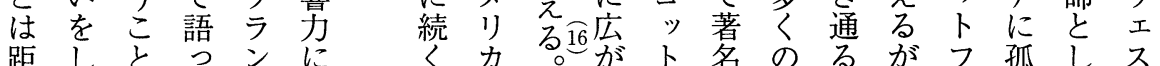

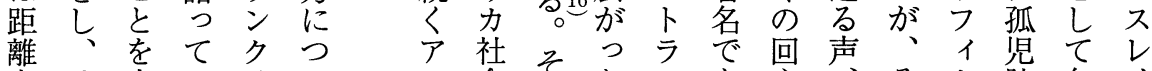
置こ栗る

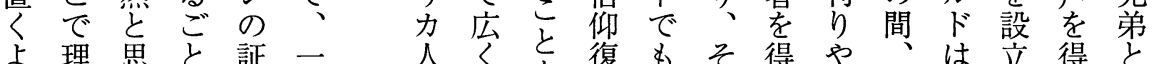

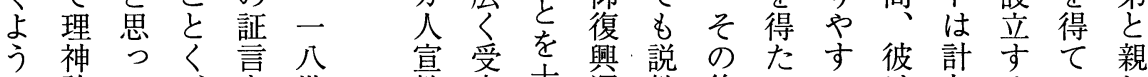

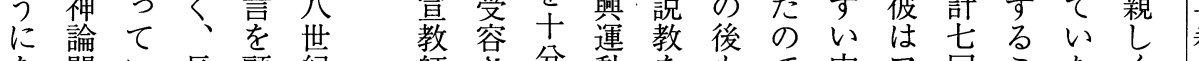

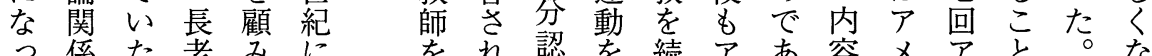

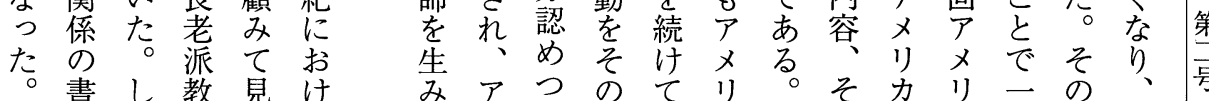

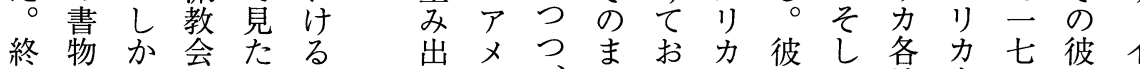

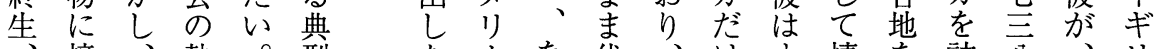
接、熱。型た力な代、けす、情を訪公、リ 宗し兄忍フ的こ社㧍表そでで緒説机年アス

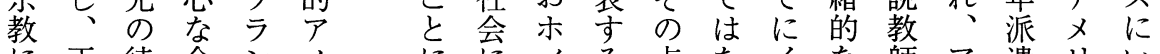
に正徒会ンメににイる点なイな師ア遣リい

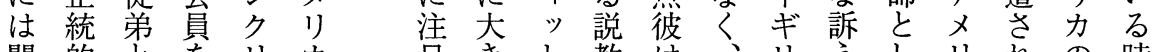
関的とをりカ自き卜教は、リ爫しリれの時

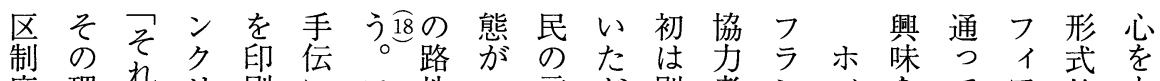
度理れリ刷いフ地一言が別者ンイななてア的も な神はン、、ラの変動、とにクッく見唯なち、

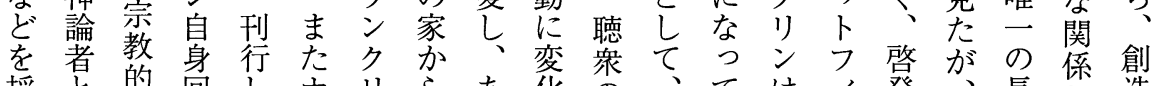

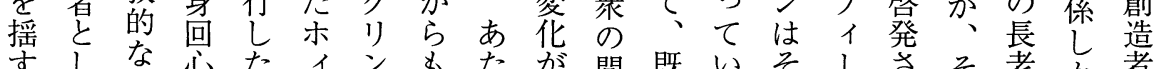
寺して

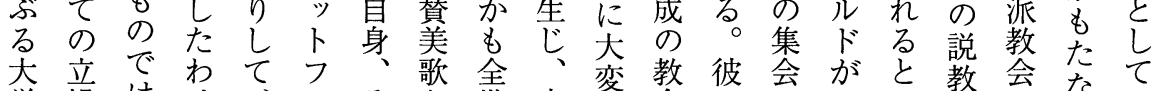

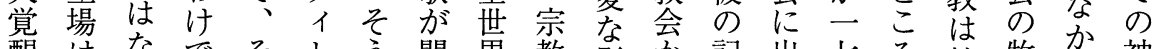
醒はなでそ।う聞界教影务記出七ろ教牧艻神 運変かはのルしこがの響ら述席言が義師たの

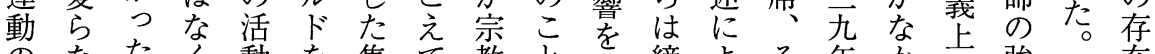
のなたく動を集て教と起締よそ年か卡強自在

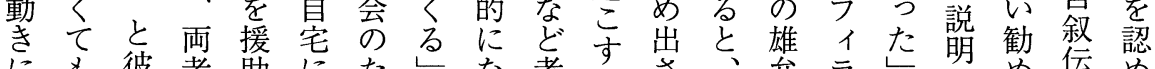
にも彼者助にたにな考にさ弁ラたにめ伝め フ 既記 交て 泊

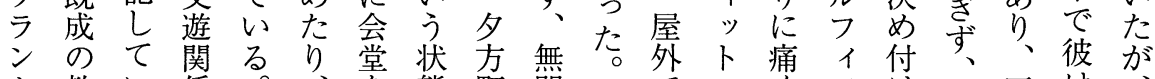

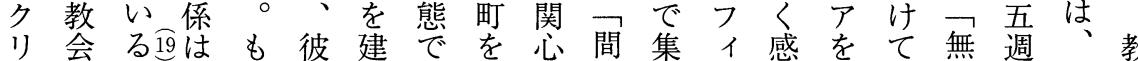

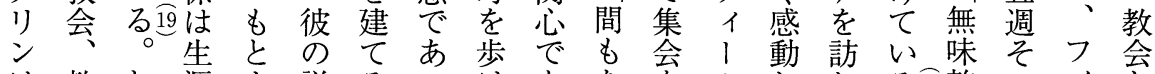

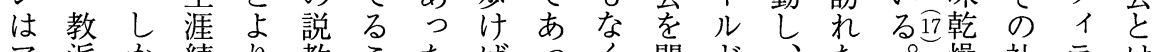
ア派か続り教こたばっく開ド、た。燥礼ラは

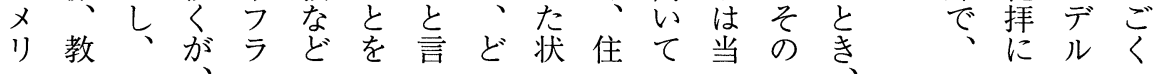


なり自まの七コ者は独に

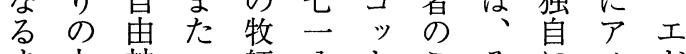
ま丸神八師八トこそにメド

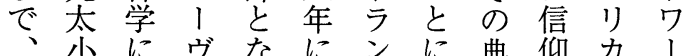

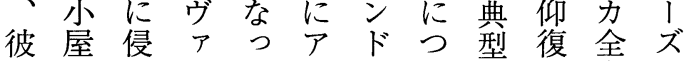

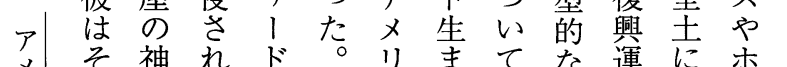

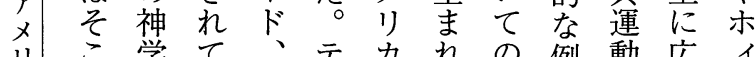
リご学て

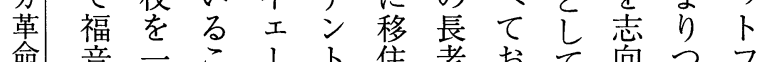
命音二こ

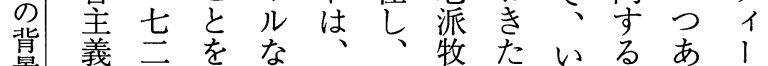
景的公批ど北フ師いわ牧るル

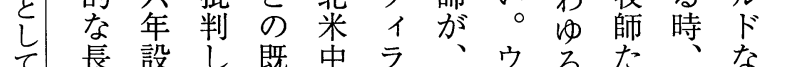

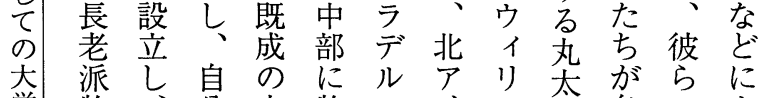

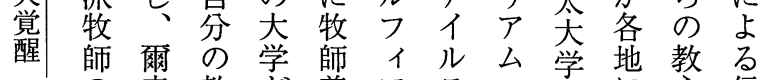
の来 教が養アラ・学化え信

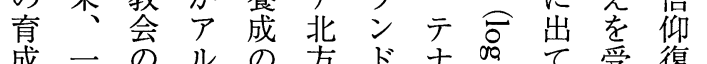
成二近ミ機方在ン方来浮興

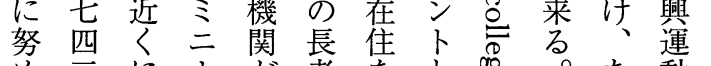

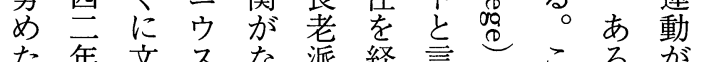

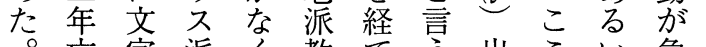

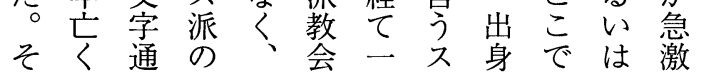

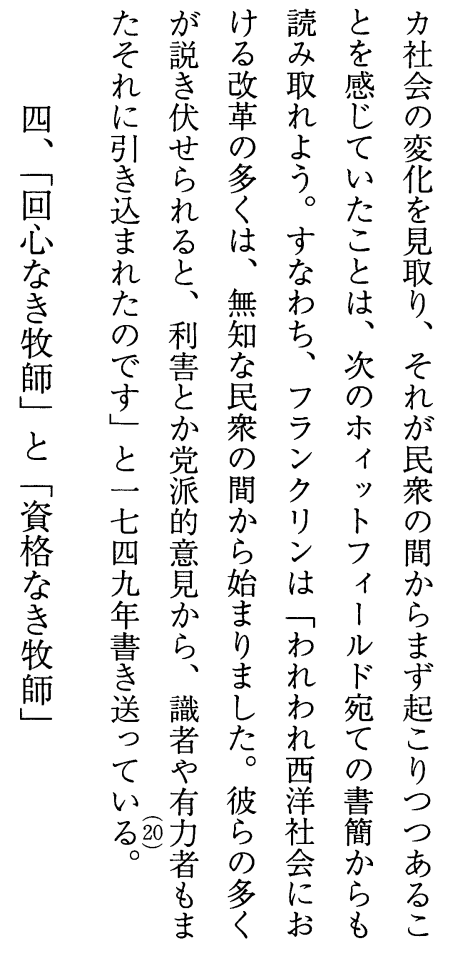

を八中くてれがの摇ル説判よに卒教る巡るの

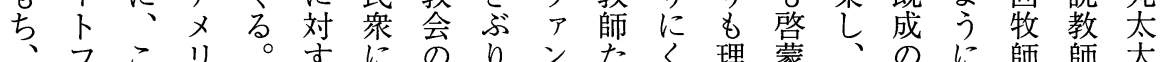
一才称当る浸形捉主ちく性主学教なと学 七1を人初既透式交義は、封識会っし牧名 四ド批のは成し化穴、無重の教たて師ら

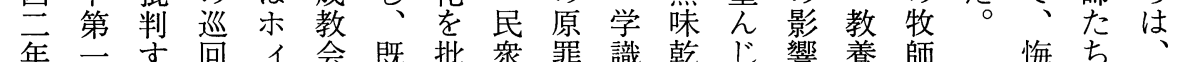
に教る牧ッの成判に、こ燥るをはたが自

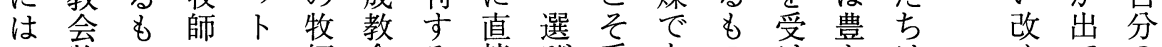
コ牧ののフ師会る接び交のの活かはめての

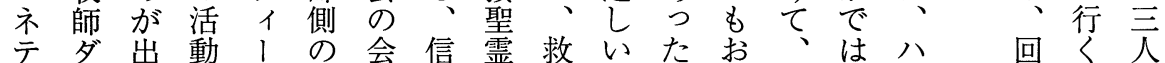

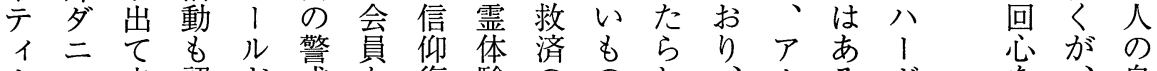
カ工来認ド戒た復験ののし、方ヴ息

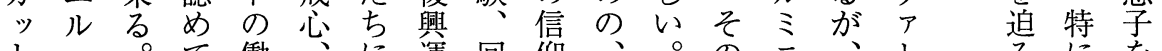

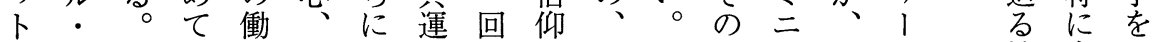

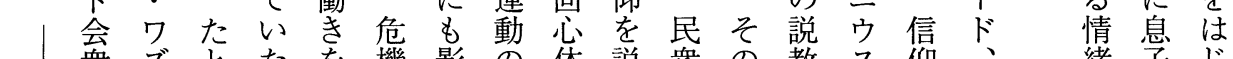
三圌

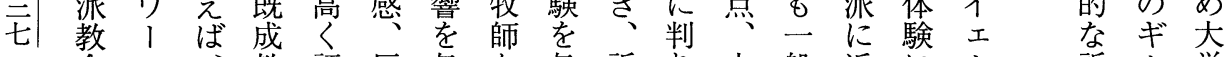
会ス、教評反与た与訴り大般近にl訴ル覚 ははコ会価発えち学や覚のく立ル醒

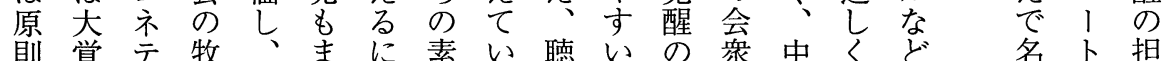

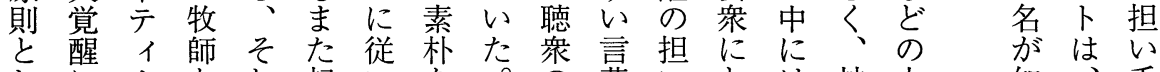

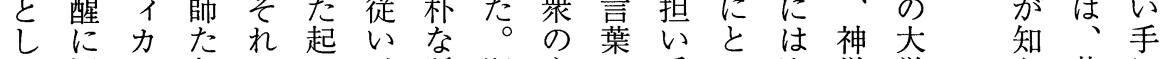

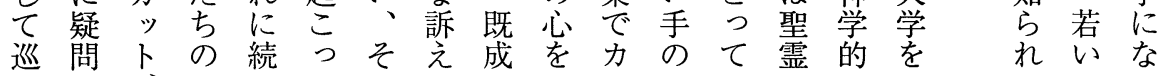




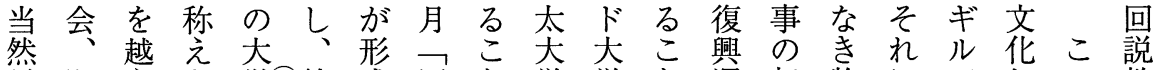
長既えた学玨彼式回々学学と運起牧に心゙しの教 老成てのを学的心を出卒、動こ師対!た既を 派大他で腐を権な拒の業つ的りの抗卜も成禁

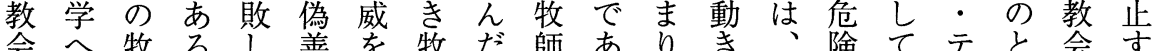

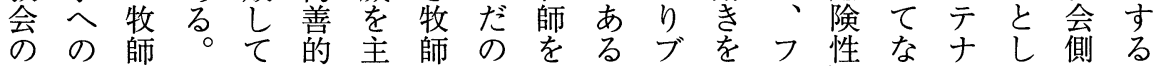

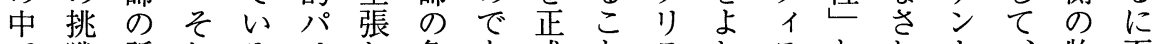
で戦訴し る

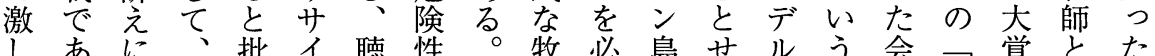

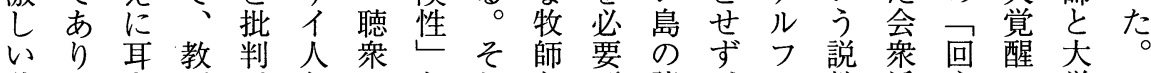

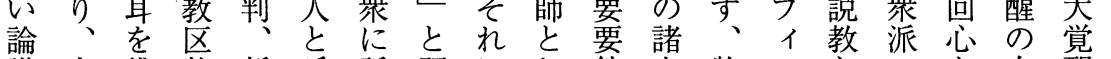
議古貸牧新呼訴題にし件夲牧アと年な 有醒 をき考師しび方対てと学師長の牧き方側 呼教よのい、るるし認しかの老応師牧なの び区う説私八説説てめた、資派酬浔師推牧

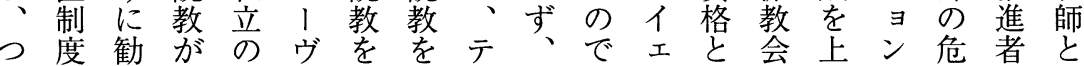

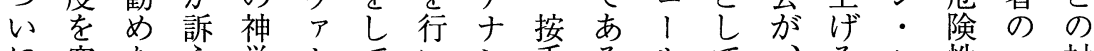
に突た学

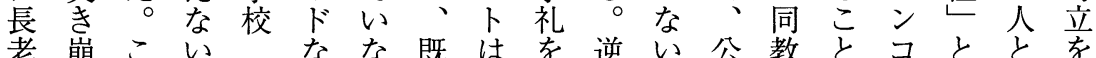

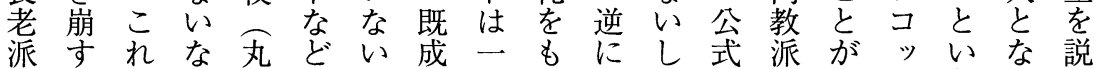
教もはら态のこの方っ言公のの出クうう教 会の、ば古と教四て之、大中来の説たの はで既、学いを教り任ばヴ学の占教卡形

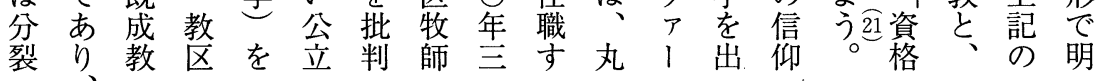

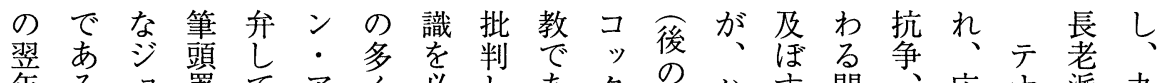

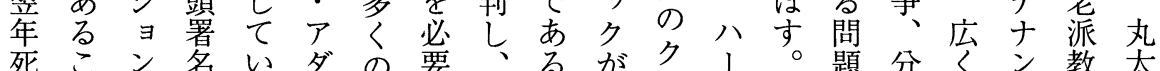

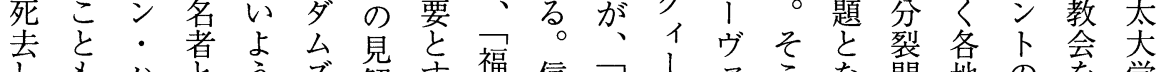

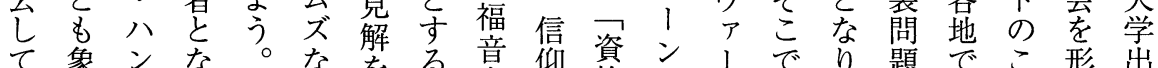

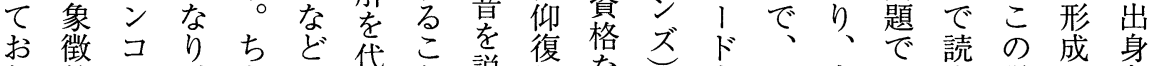

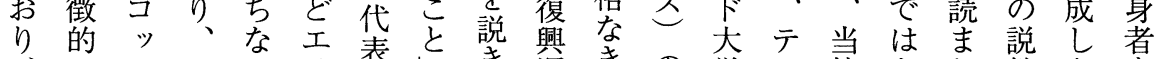

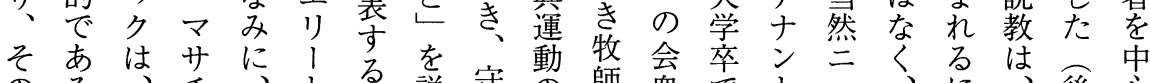

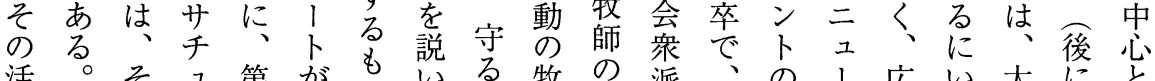

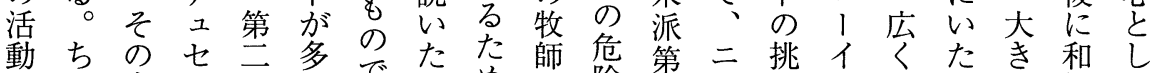

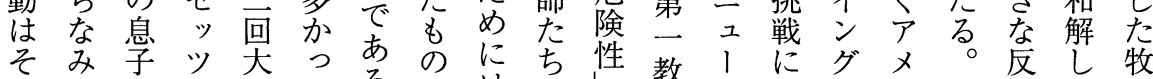
れにこ州陸たろではに势イ正ラリ問響再師

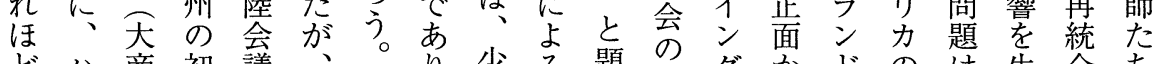

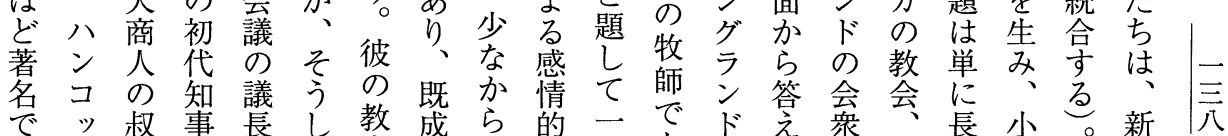

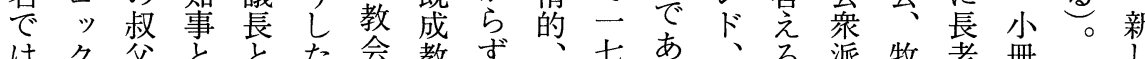

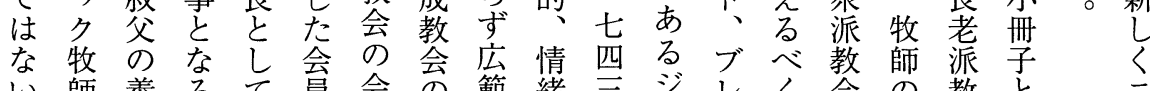

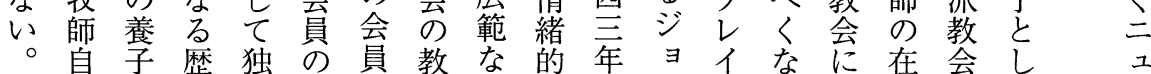

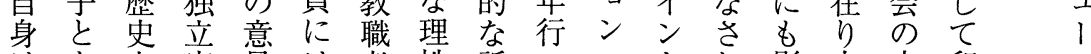
はな上宣見は者性訴っ・卡影方内印妇

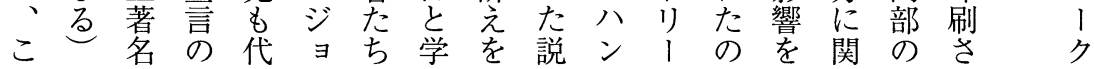




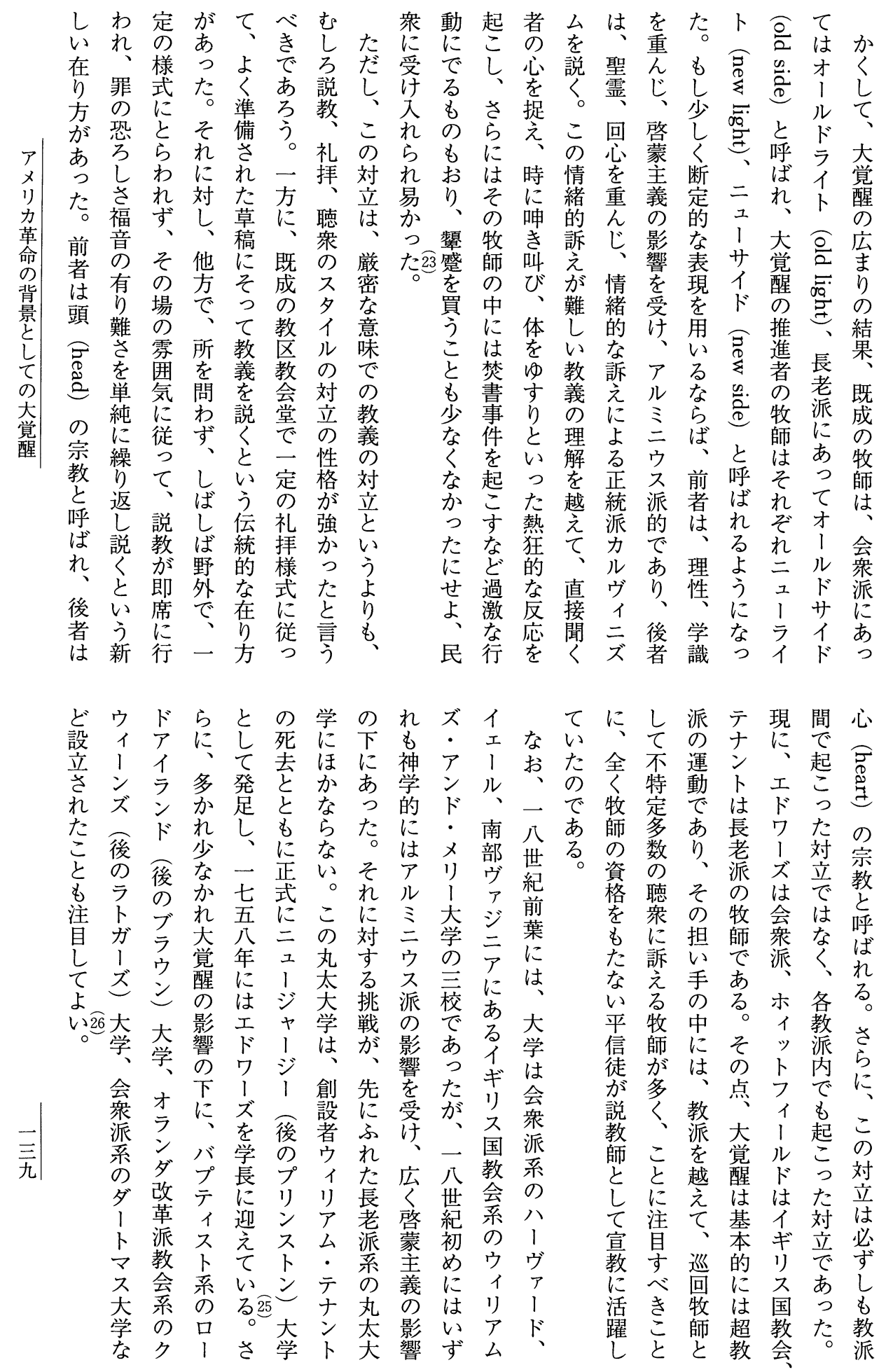




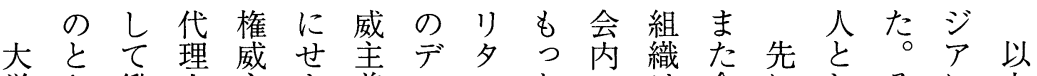

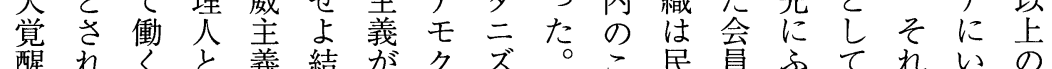

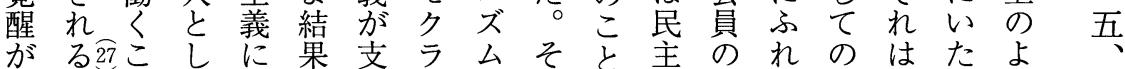

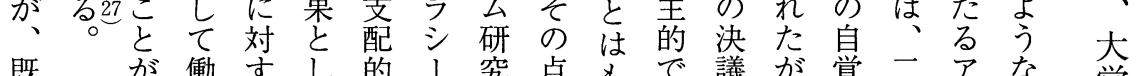

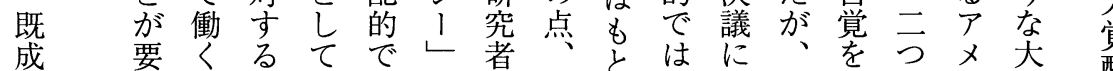

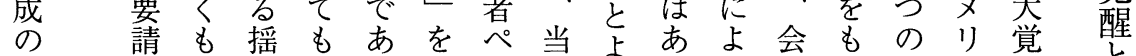

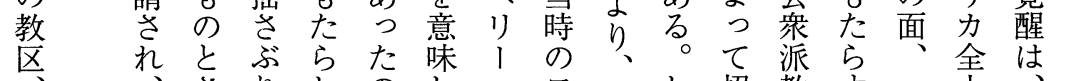

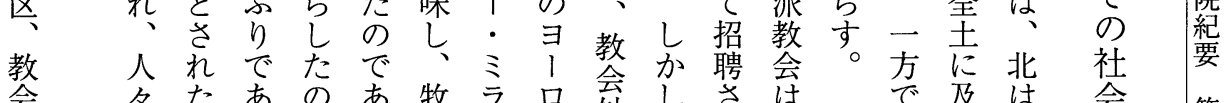
会々たあの市牧ラ口俞し岂は令及は

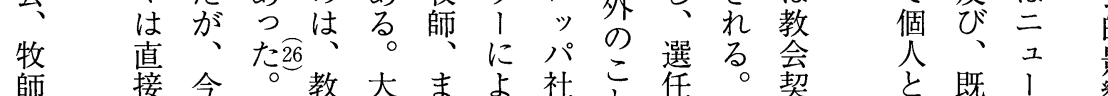

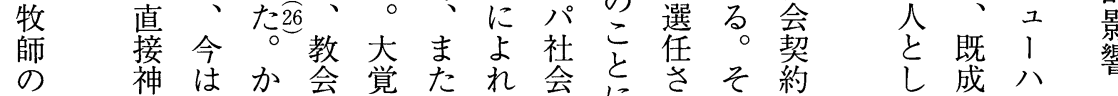

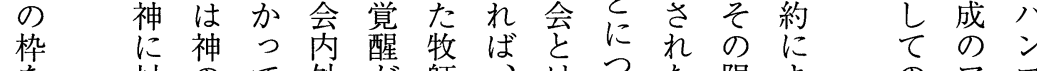

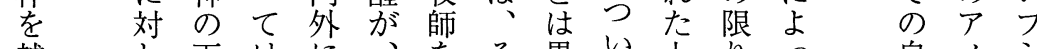

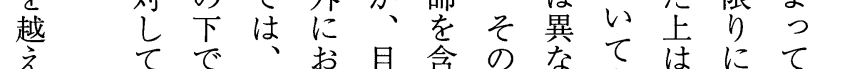

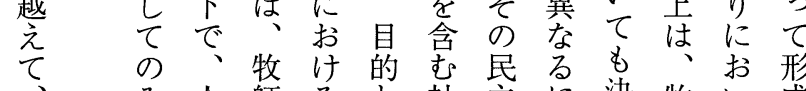

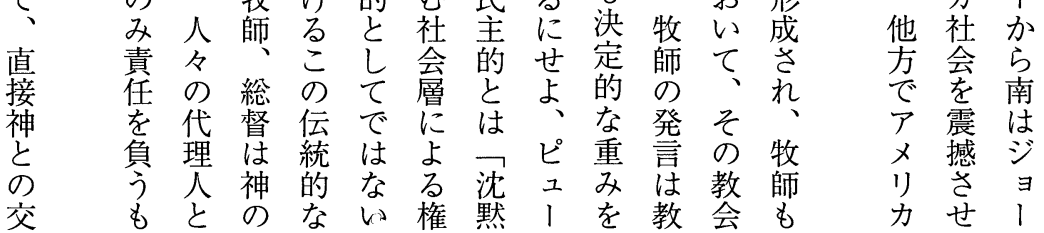

信しの民抗こた的なけ教つ個のの仰に付わ 徒、な重兵議と離にかる上名教増復存いり の少挍要集は拄自にデのり、の会妿興在てを

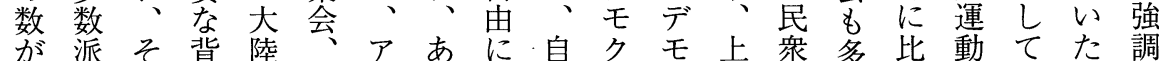

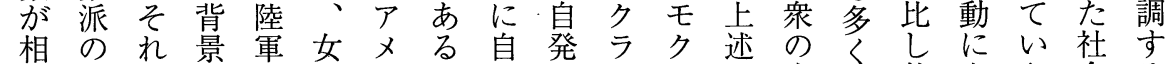
対教と学な性りい発的シラし自な牧もた会る 的派関などを力は的結、シた信る師個平の事 に、連すの含䩗解に社の!ギとるの人信階に 堌す

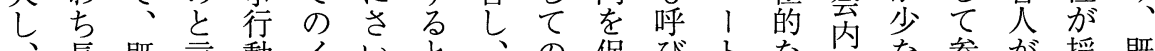

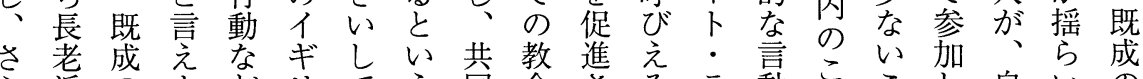
に派 の

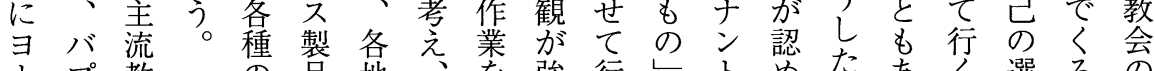
了プ教の品地、㙖行レトめ傾あ傾選る。

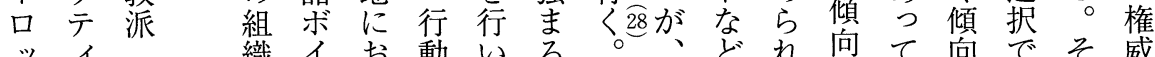
パス国 織 イ

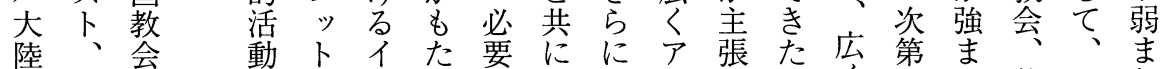
かメ へ運ギら

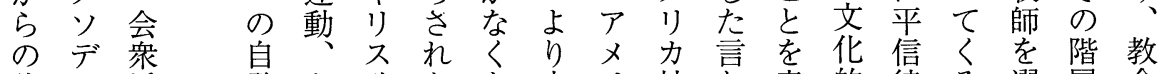
諸々派発さ政たな広り社点意的徒方選層会

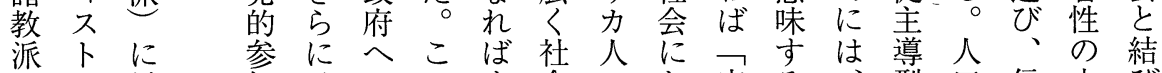

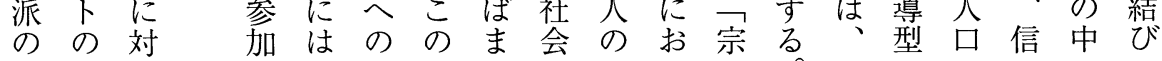




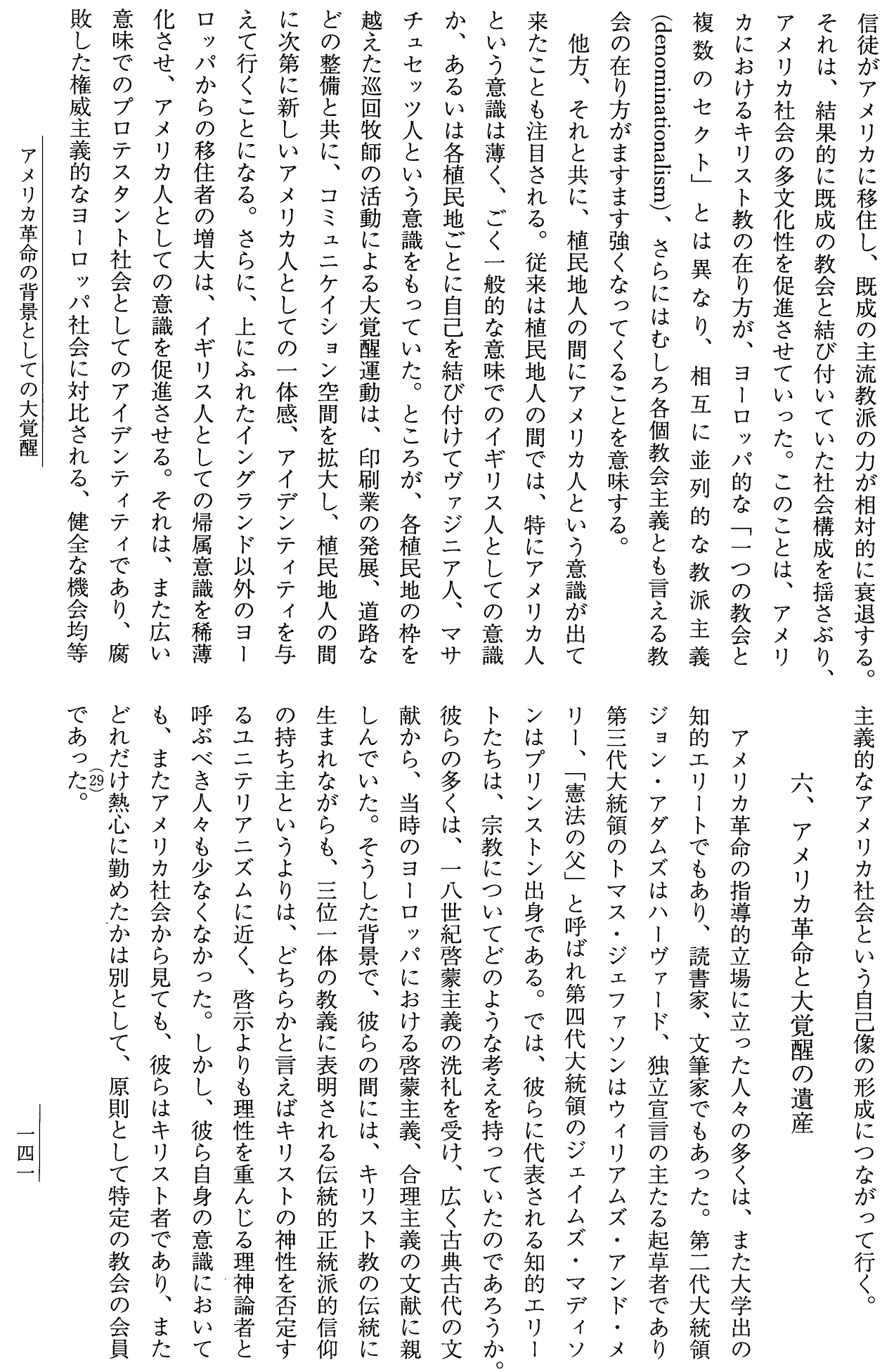




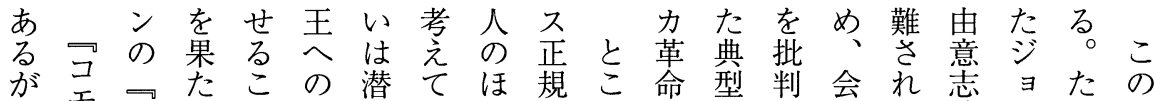

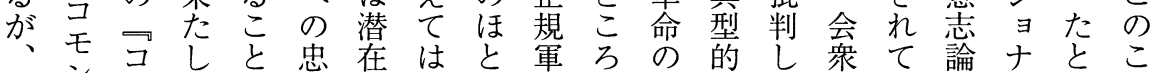

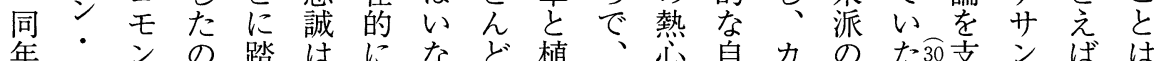

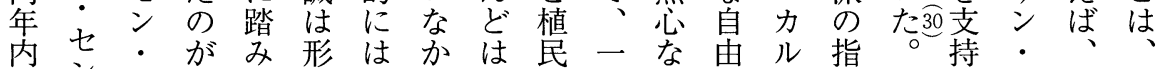

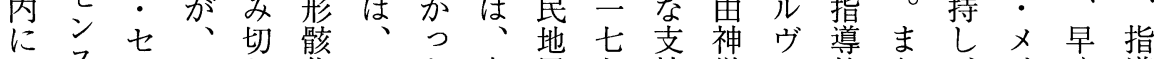

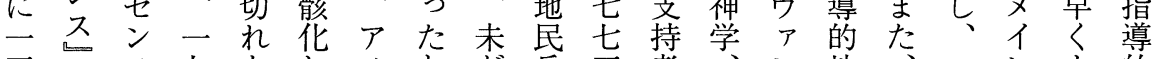

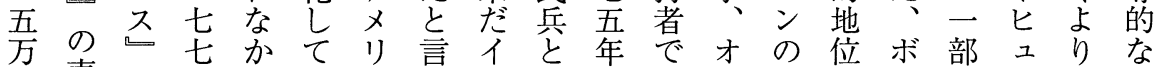
部売に六ついカつギの四あ、予にス交牧 売放たてのてリ間月っル定い下ら牧権師

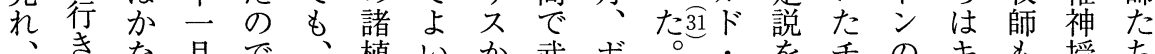

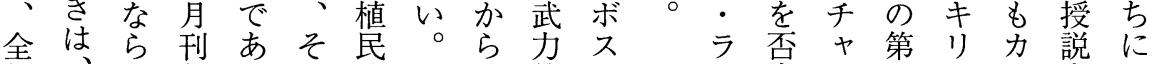

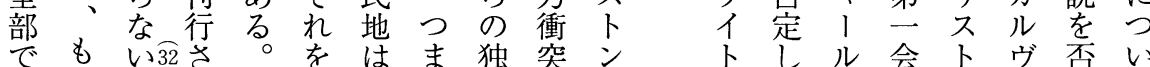

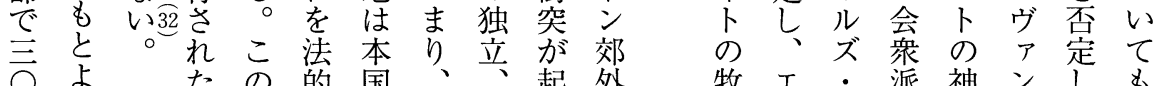
万り 方潜な的国な国走多

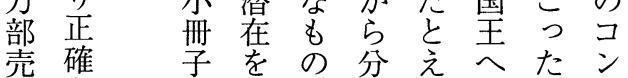
れな、顕と離事の後コ

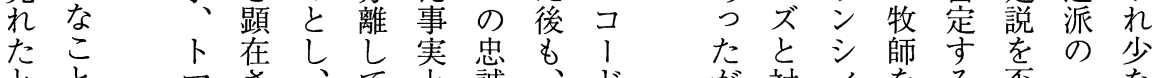

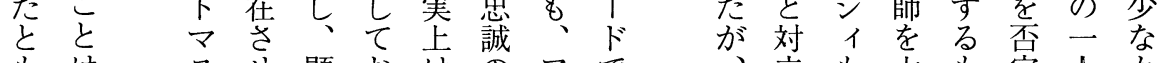

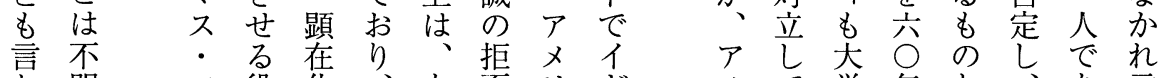

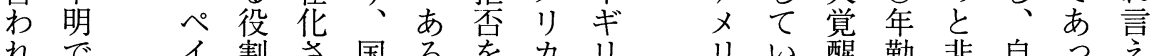

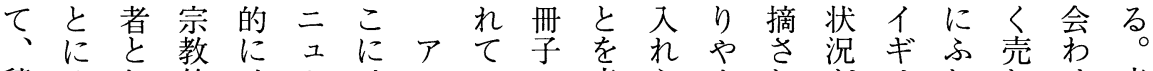
積晚し的は、はメいの当らすれ少りれ洦当 極年てに、ト父リる中然れいるあるた

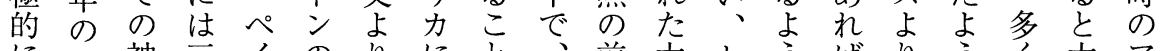

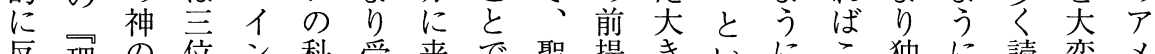
反理の位ン科受来で聖提きいにこ独に読変メ 聖性存示の学忛るあ書となう立立まなり

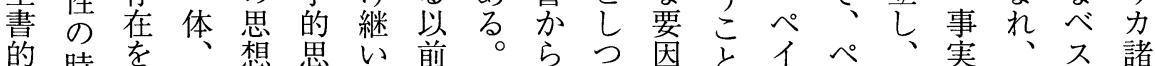

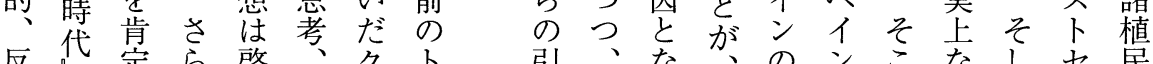

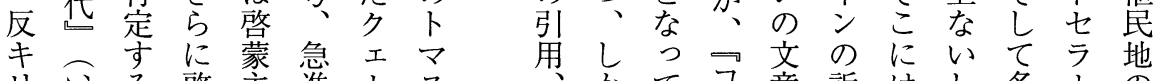
リ

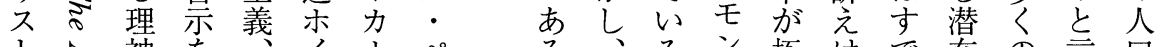

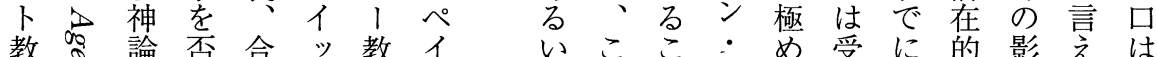

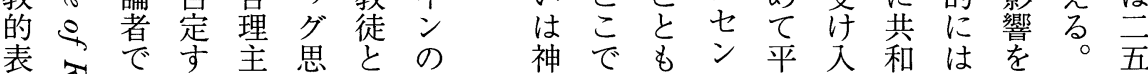

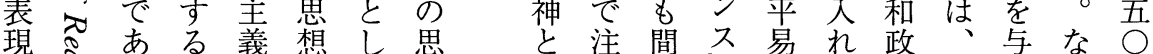

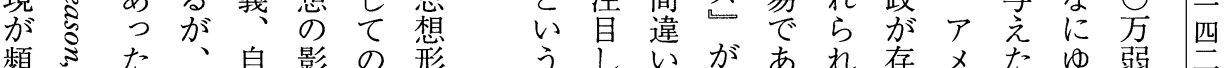

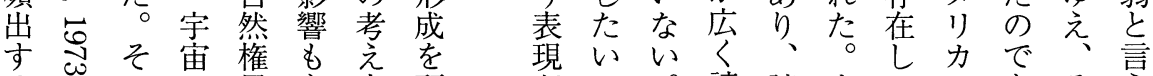

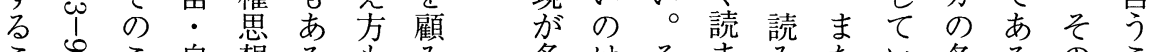

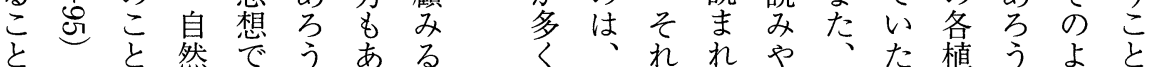

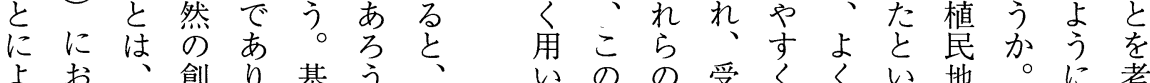

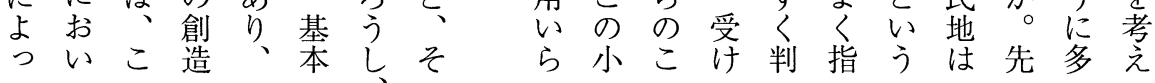



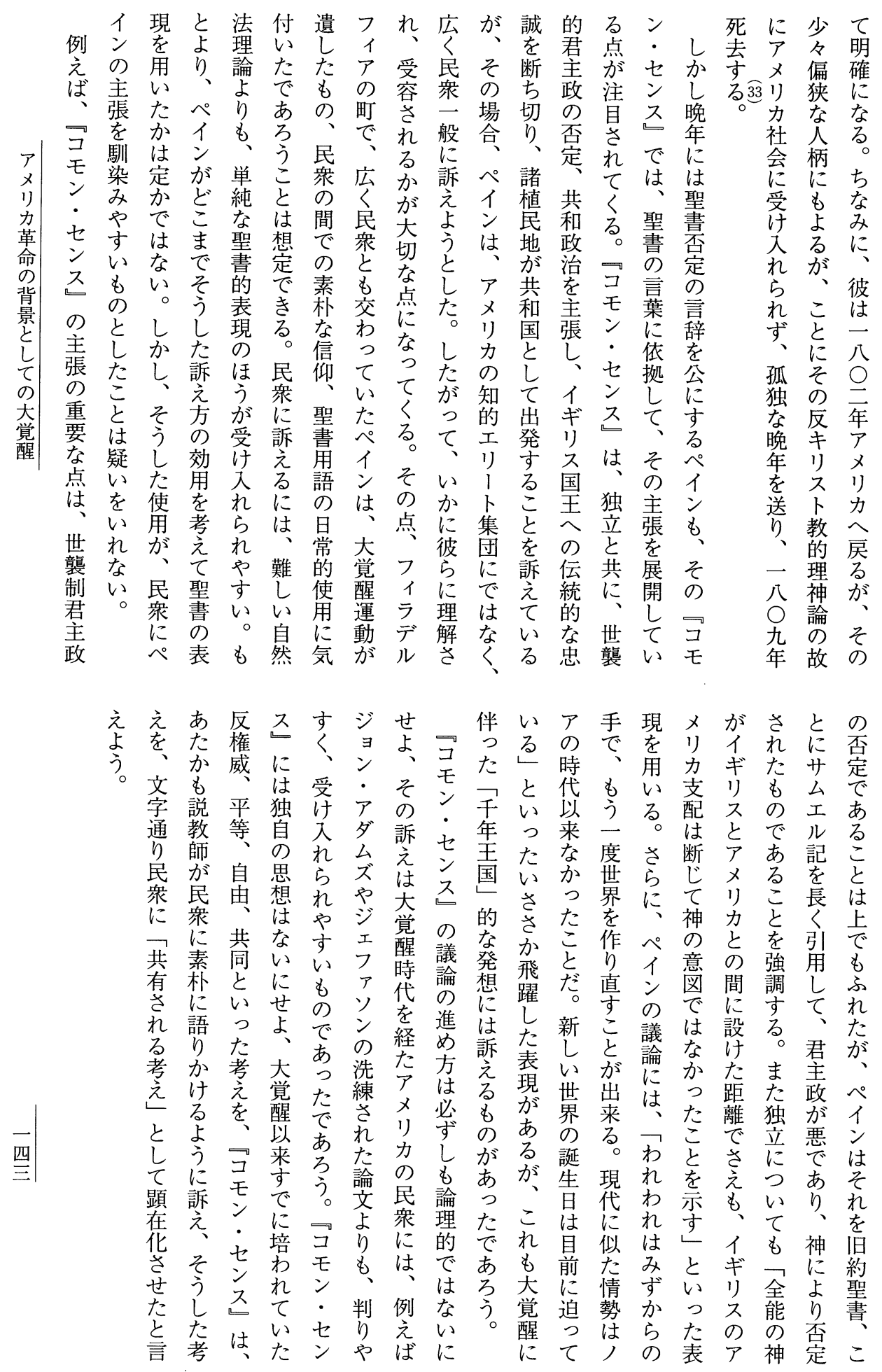


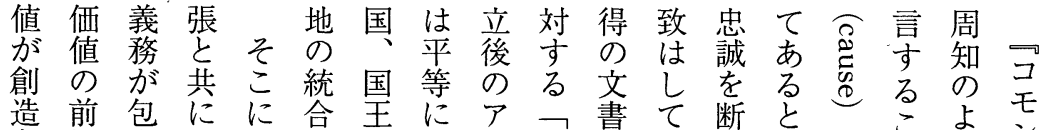
著提含留

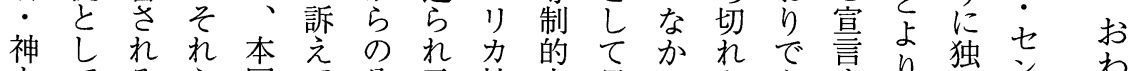
かてるら国尔分云社支長つなあ高り独之わ

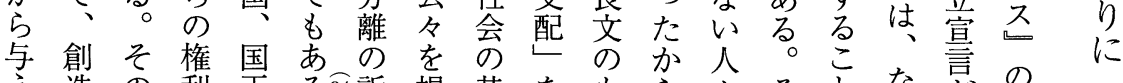

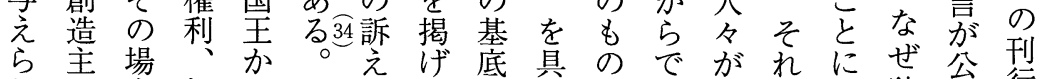
れ. 合偠らで、集であ多はあ独布後

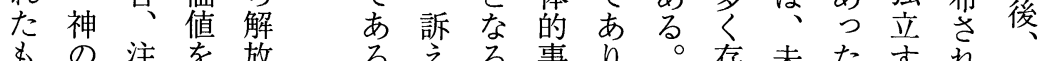
もの注を放劣劣事り。存未たす例半

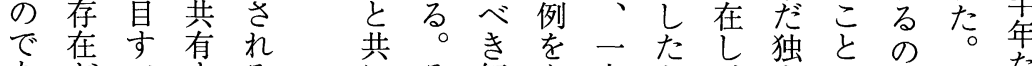
あがべするにに価も方が、立は独た る記きべべきの值つでつ三に踏独立章

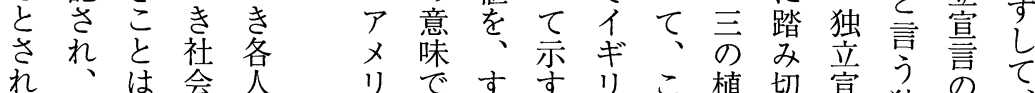

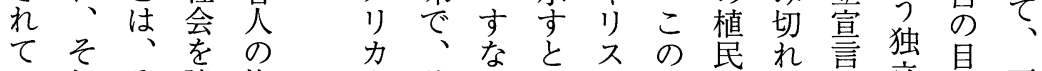
い机建権、独わ共国独地な高立的二

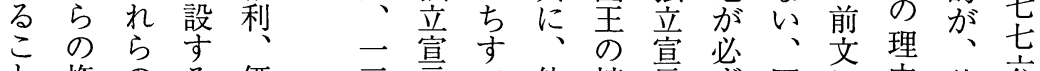

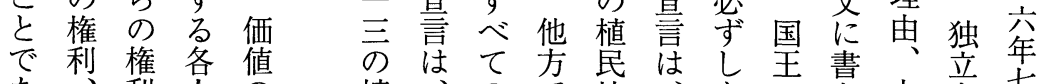

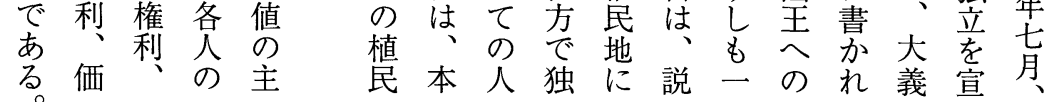

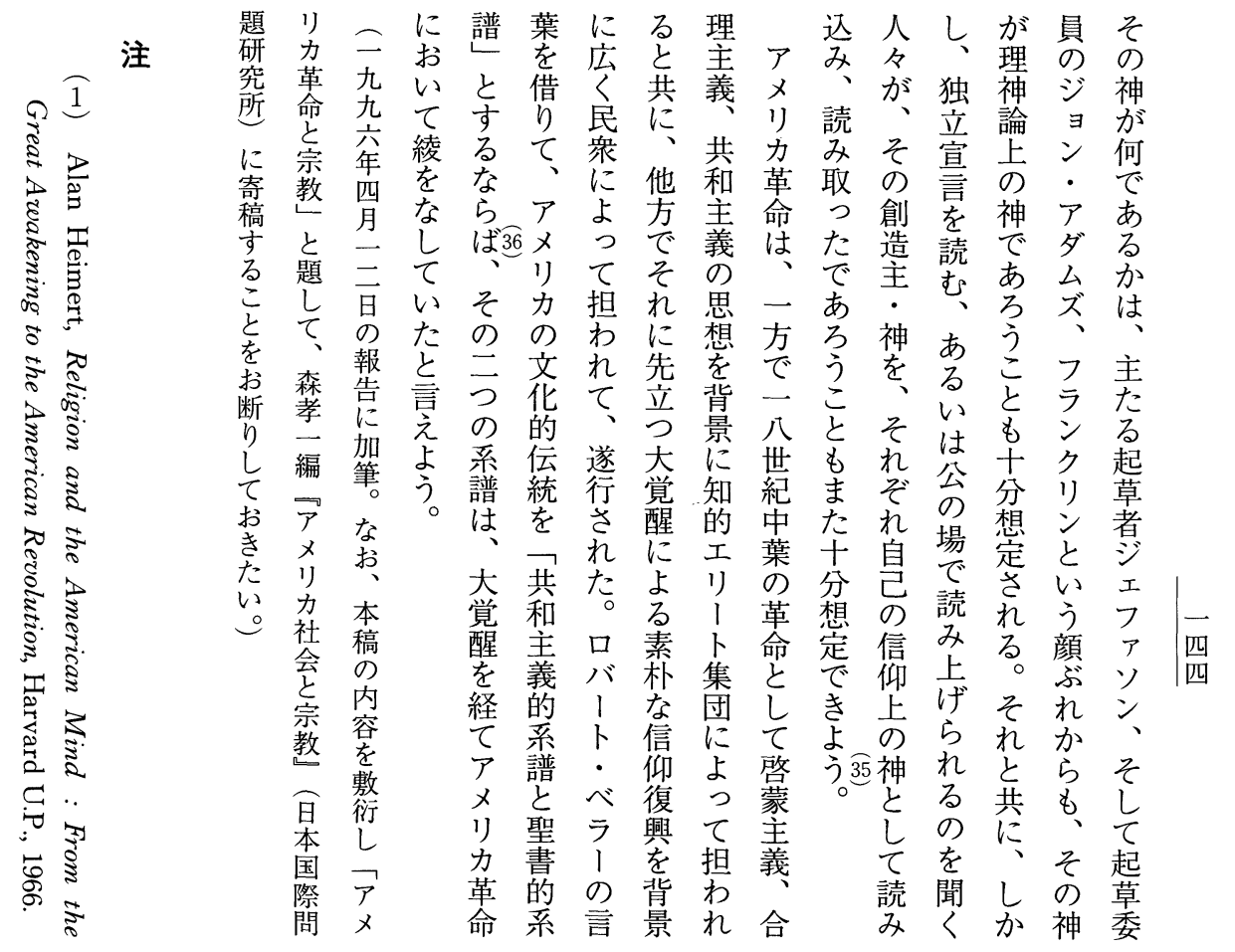



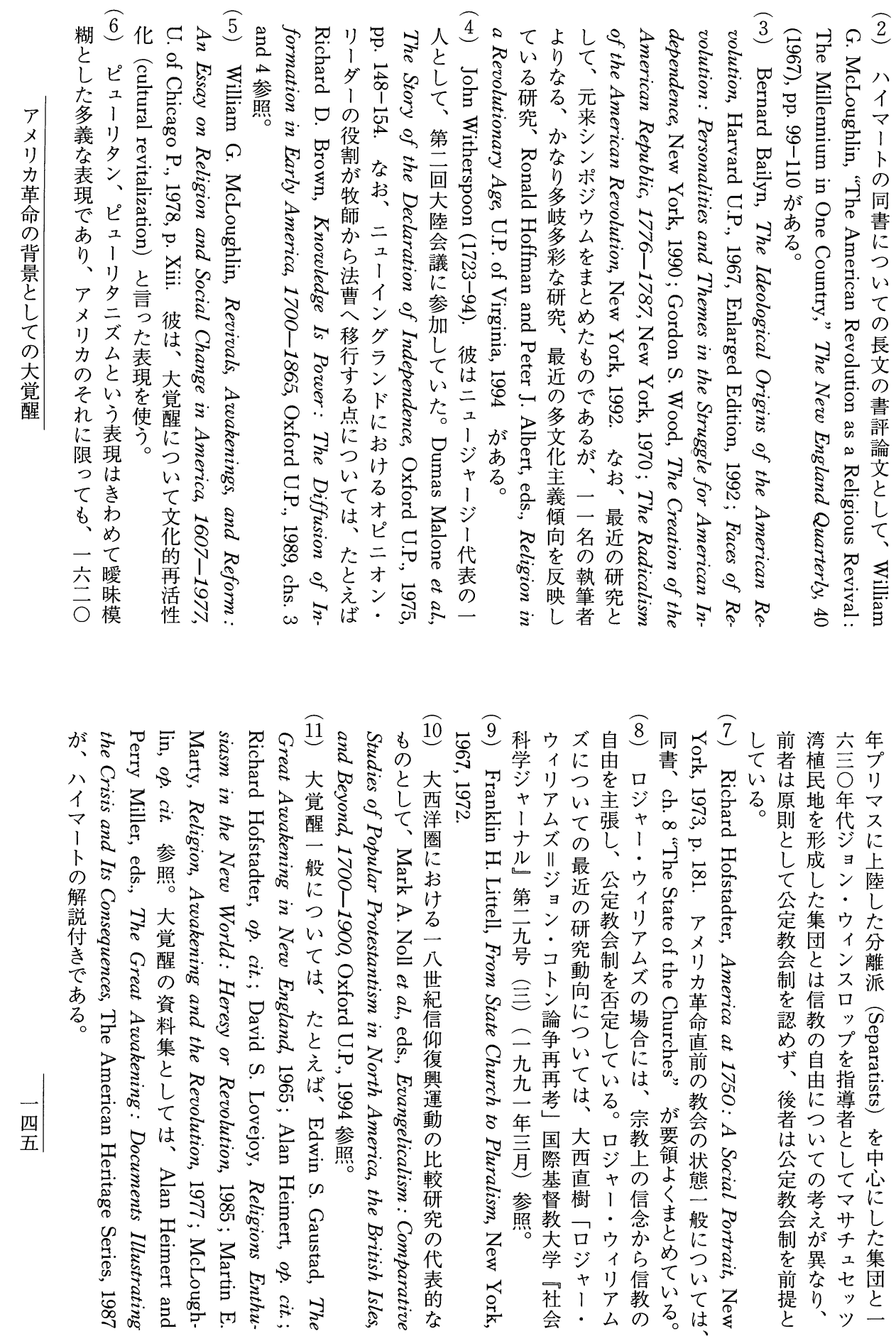


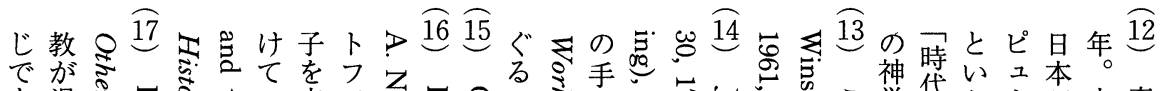

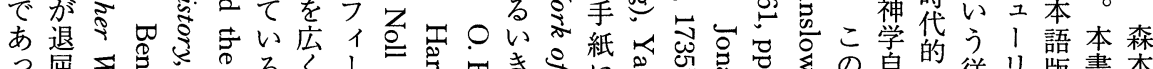

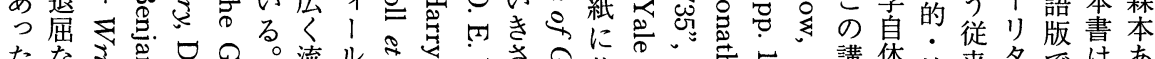

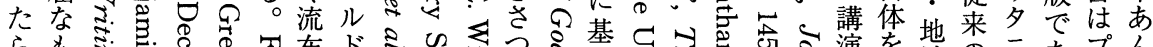

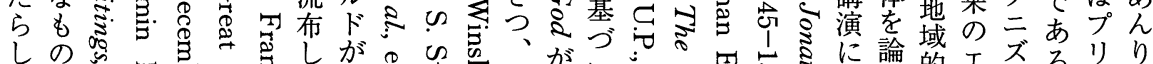

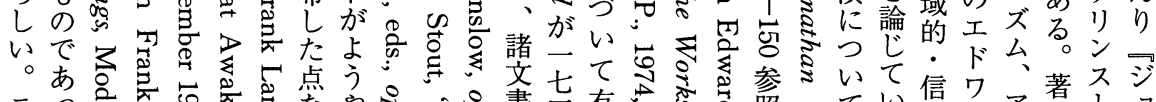

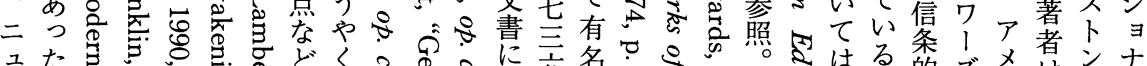

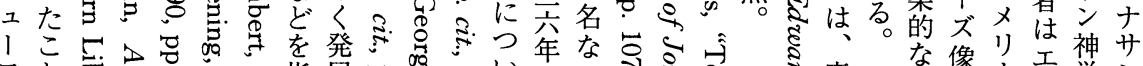

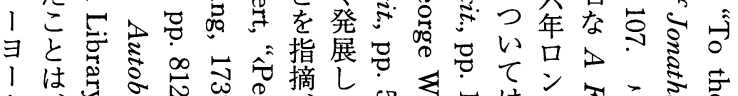
ク

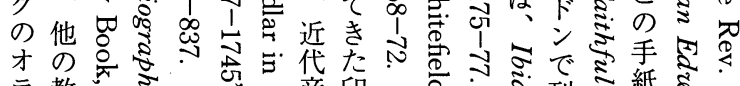

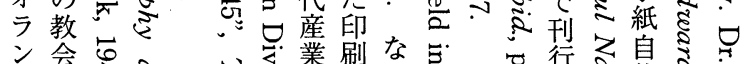

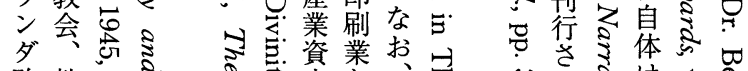

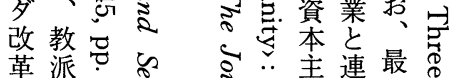
革派它

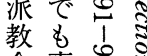

会事选

の 情 義携近 $尺$ $\omega$

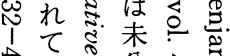

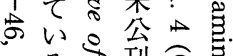

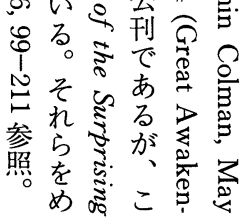

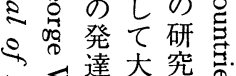

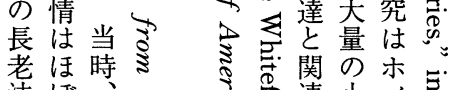
院同説密

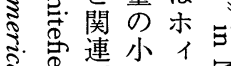

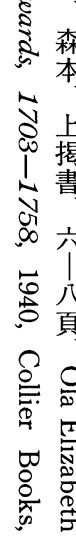
像力エ学シ 等越的卡夲 を越斗学工

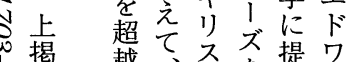
書越、贞を出!

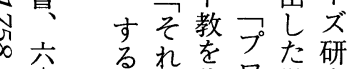

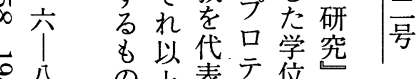
頁と上衣諭創

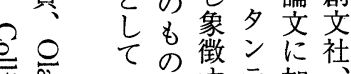
エの待テ妿 四志特る亿筆二

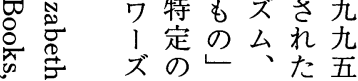




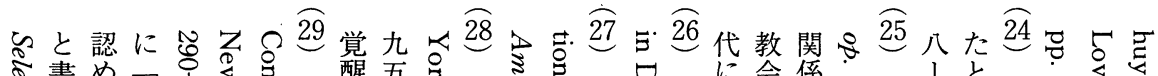

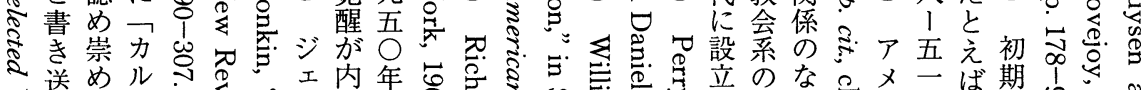

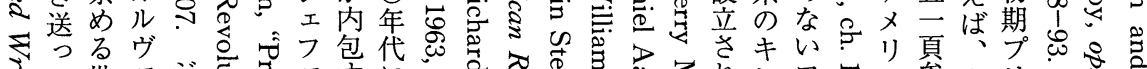

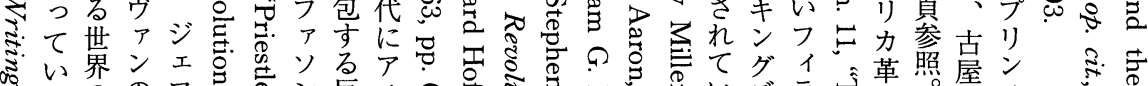

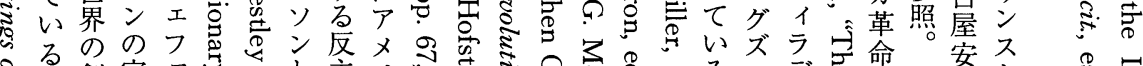

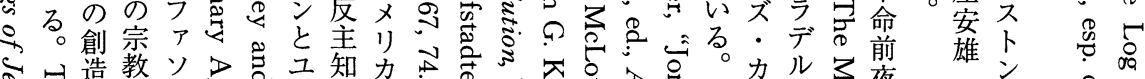

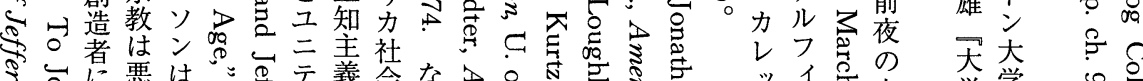

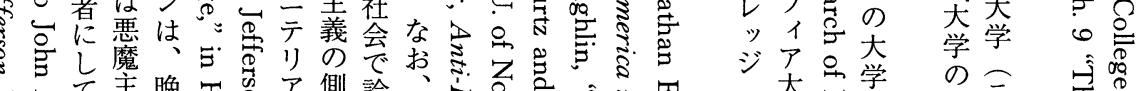

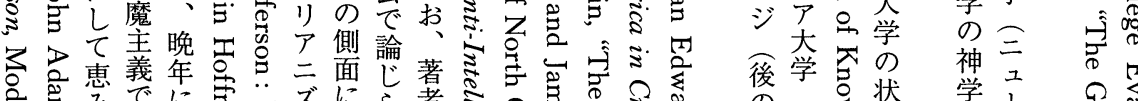

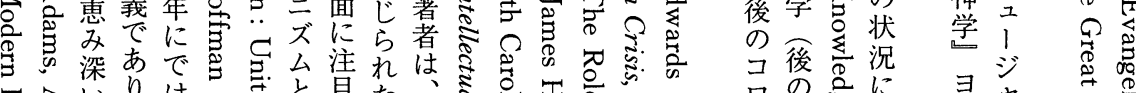

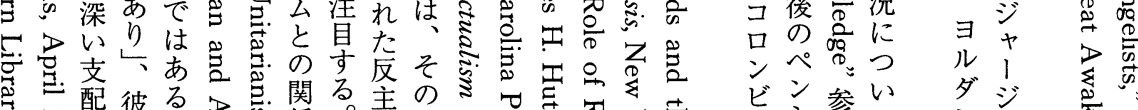

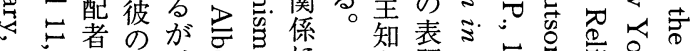

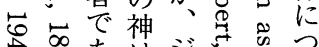

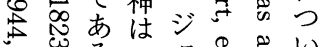

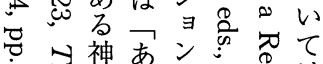

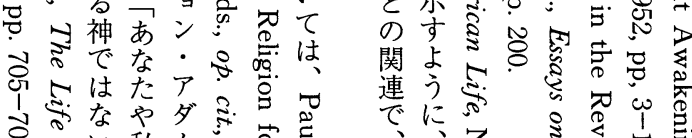

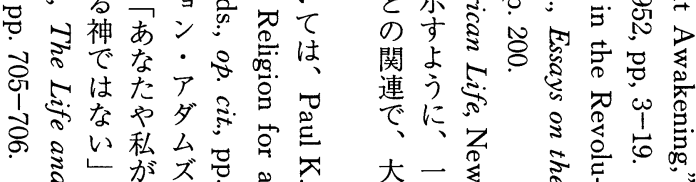

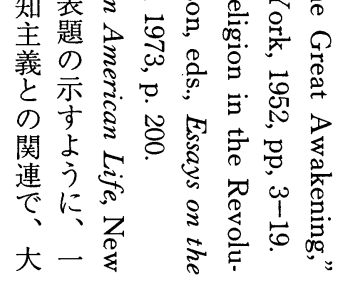

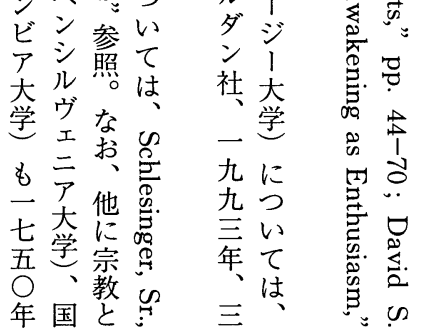

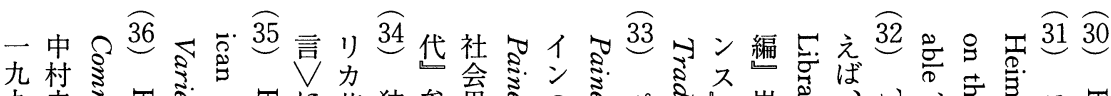

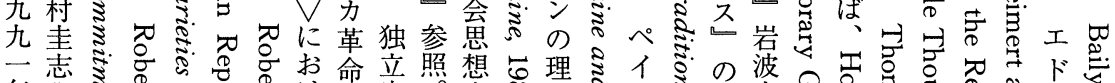

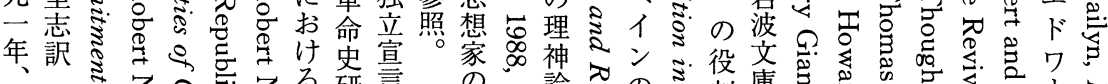

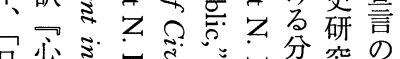

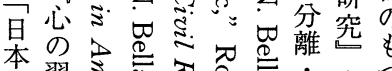

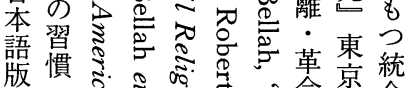

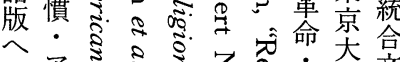

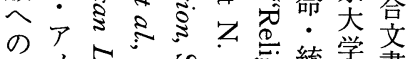

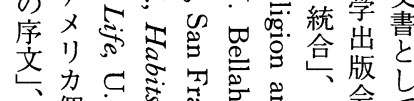

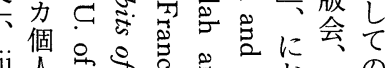
vii

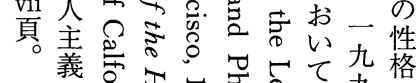

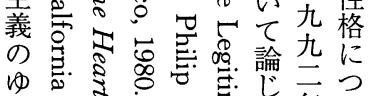

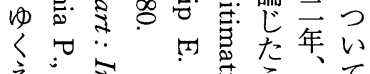

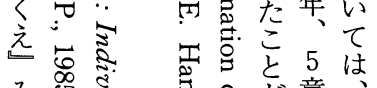

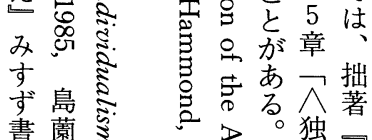

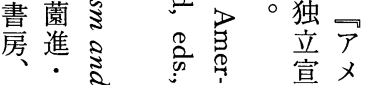

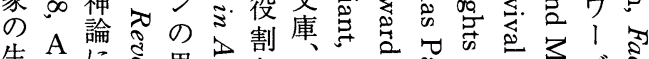

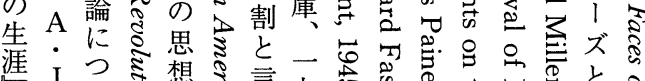

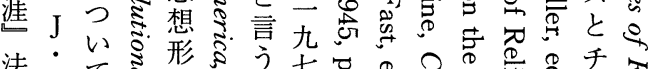

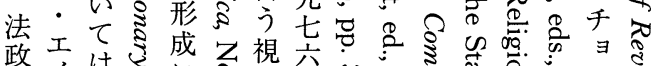

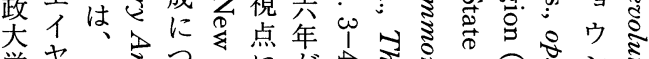

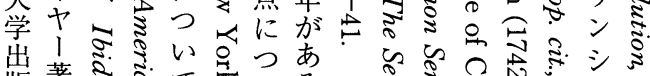

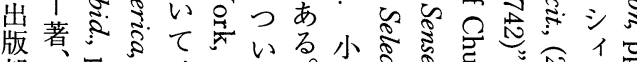

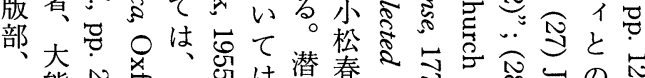

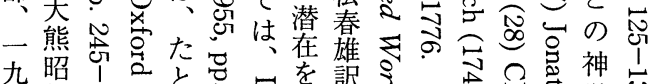

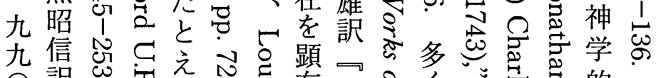

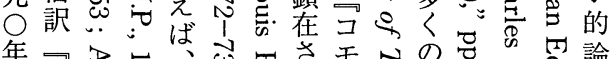

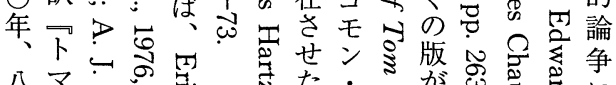

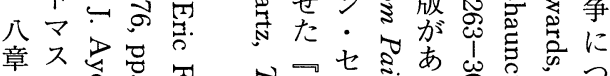

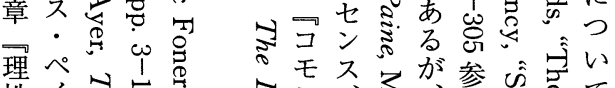

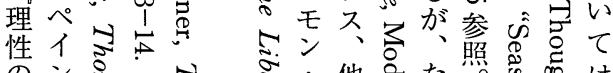

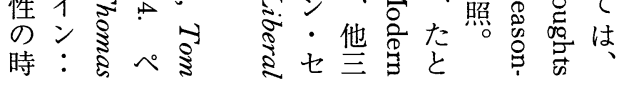


with their ideals of Enlightment, Rationalism and Republicanism was vital to promote the American Revolution. Yet, the American Revolution was widely supported and accomplished by the populace with their simple-minded religious and biblical populism as well. 


\section{The Great Awakening as a Background of the American Revolution}

Makoto SAITO, M.J.A.

It is now widely accepted without argument that the American Revolution brought forth the dissolution of the established church system and the establishment of religious freedom as tangible results. The role of religion as a theoretical background of the Revolution, however, has not reached any agreement among the scholars. Alan Heimert evaluated the significance of Calvinism as a direct contribution to the Revolution. Bernard Baylin and Gordon S. Wood, on the other hand, put much emphasis upon the influence of Republicanism. Admitting the fact that religion did not directly cause the Revolution, I would like to point out the significance of the Great Awakening which covered the English America with spiritual excitement in 1730's and 40's. The role of religion should be evaluated as a spiritual preparation of the Revolution among the populace.

In the beginning of the 18th century, church activities dwindled into a stale condition under the intellectual but un-converted pastors, who had been theologically influenced more or less by Arminianism. There was a schism among the congregation in terms of social strata. On the other hand, in 1730's, Jonathan Edwards and George Whitefield among others, in spite of their very different type of character, initiated the revivals, which enhanced believers' direct access to the Divine, voluntary religious meetings and the active participation by the laymen in religious activities. These phenomena caused the transformation of religion in American society, which inevitably entailed the change of society itself. The activities of itinerants in the Great Awakening have also contributed to create new American identity, which surpassed the regional boundary among colonies.

Thomas Paine's Common Sense, whose tremendous impact as a trigger of the American Revolution has been pointed out, draws our attention in this context. It is certainly interesting to note that Paine, a deist, quoting widely from the Bible, made it easy and convincing for the populace to accept the appeal of independence and antimonarchical sentiment. The role of the intellectual elites 